Spring 5-6-2013

\title{
Fit to Care: An Action Research Study Exploring the Use of Communication Theory to Strengthen Caring Relationships between Teachers and Students
}

Pamela K. Lake

Follow this and additional works at: https://scholarworks.uttyler.edu/nursing_grad Part of the Nursing Commons

\section{Recommended Citation}

Lake, Pamela K., "Fit to Care: An Action Research Study Exploring the Use of Communication Theory to Strengthen Caring Relationships between Teachers and Students" (2013). Nursing Theses and Dissertations. Paper 32.

http://hdl.handle.net/10950/107 
FIT TO CARE: AN ACTION RESEARCH STUDY EXPLORING THE USE OF COMMUNICATION THEORY TO STRENGTHEN CARING RELATIONSHIPS BETWEEN TEACHERS AND STUDENTS

by

PAMELA K. LAKE

A dissertation submitted in partial fulfillment of the requirements for the degree of Doctor of Philosophy Department of Nursing

Barbara K. Haas, PhD, Committee Chair College of Nursing and Health Sciences

The University of Texas at Tyler May 2013 
The University of Texas at Tyler

Tyler, Texas

This is to certify that the Doctoral Dissertation of

\section{PAMELA K. LAKE}

has been approved for the dissertation requirement on April 4, 2013

for the degree of Doctor of Philosophy in Nursing.

Approvals:
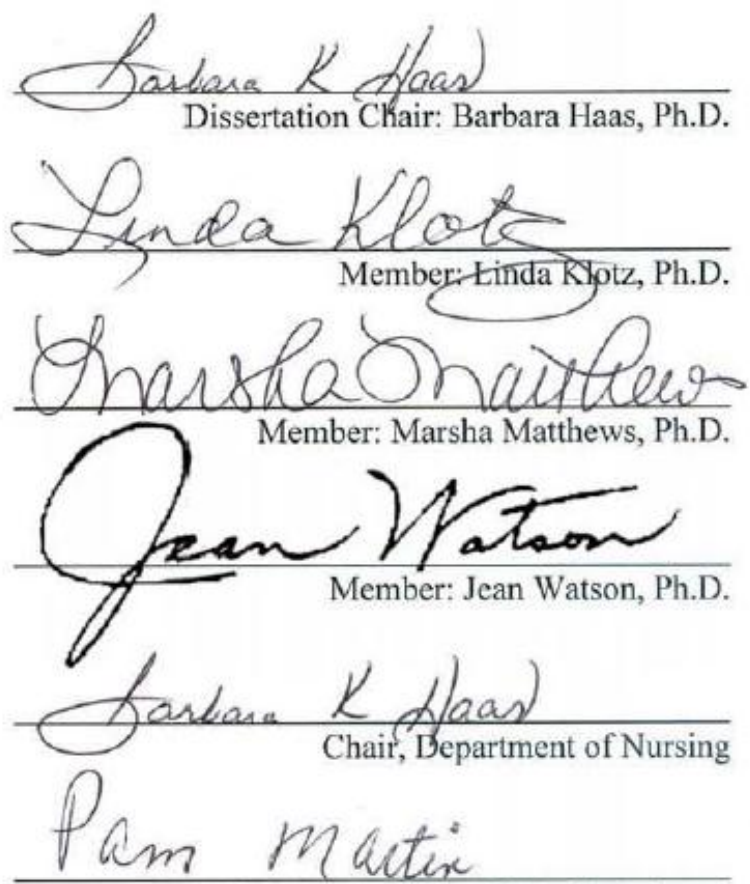

Dean, College of Nursing and Health Sciences 
(C) Copyright by Pamela K. Lake 2013

All rights reserved 


\section{Acknowledgements}

My doctoral journey has been an experience of self-discovery and expanding consciousness. The knowledge gained along the way has felt like 'coming home' rather than 'going out' into the world. I sensed an awakening to wisdom I have known before but somehow lost. My mind opened to mysteries of the universe. This type of journey does not happen without guides lighting the path. I cannot begin to mention each one who has held sacred space for me as I traveled; I hope if you are one of those, you will see your light reflected back from me, even if your name is not spelled out on this page. My dissertation committee kept me focused on the task at hand, always encouraging me to dance to my own song. You believed in me when I felt defeated and held a vision for my success when I couldn't see it for myself. I will carry each of you in my heart as an example of true mentorship.

Friends have kept me genuine throughout this process; laughing and crying with me as the situation required. You kept me from sinking into despair, but did not shy away from pointing out when ego was blinding me ("You have become your own negative case."). I love you all and our relationships have been the best part of this journey.

Finally, I thank my family for supporting my pursuit of this dream. Never once did any of you ask me why on earth I wanted to do this thing. You never pushed me forward and you never held me back. You have all been the perfect balance of unconditional love and unrelenting validation. You are my champions and the best of everything I ever hope to be. 


\section{Table of Contents}

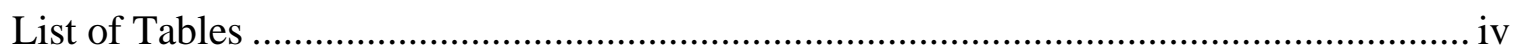

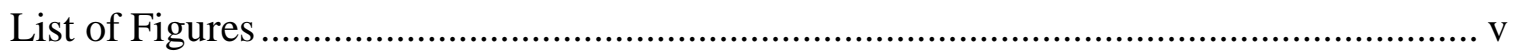

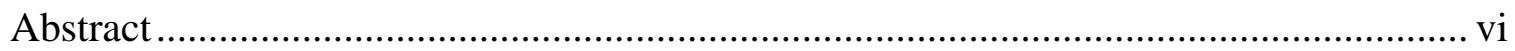

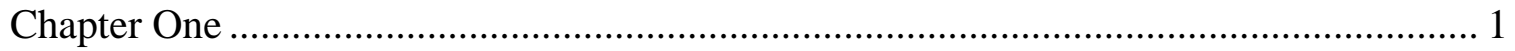

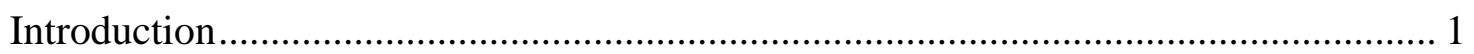

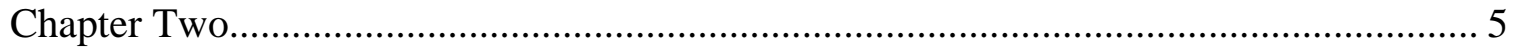

Communication Theory to Facilitate Teacher Caring in Instructional Feedback ............... 5

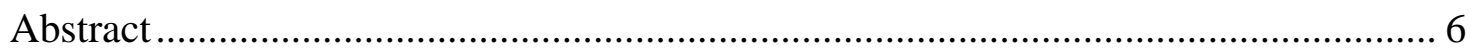

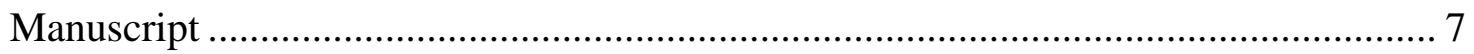

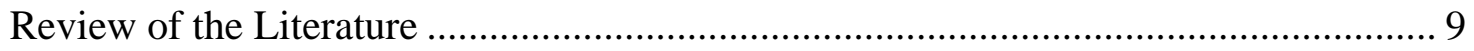

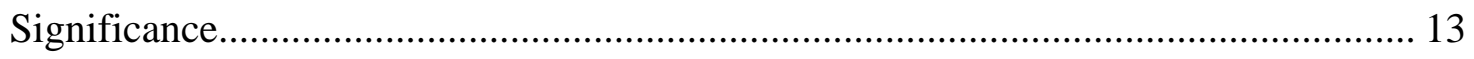

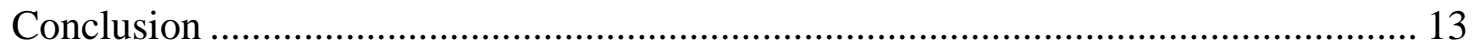

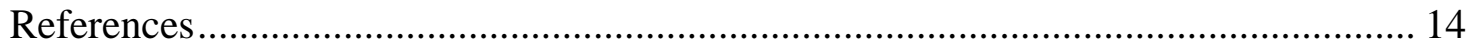

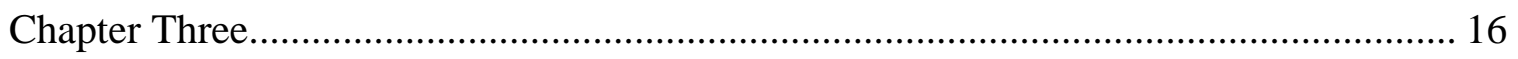


FIT to Care: An Action Research Study Exploring the Use of Communication Theory to

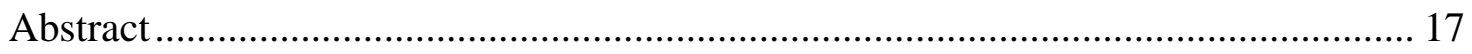

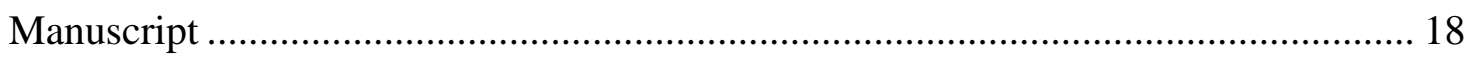

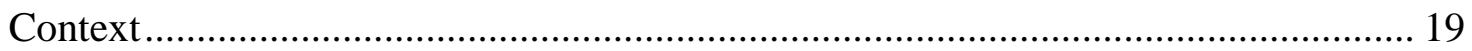

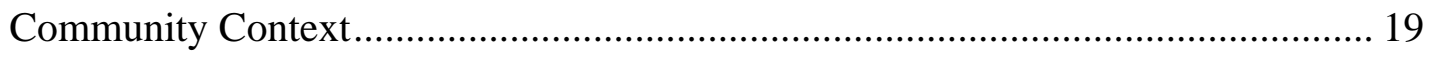

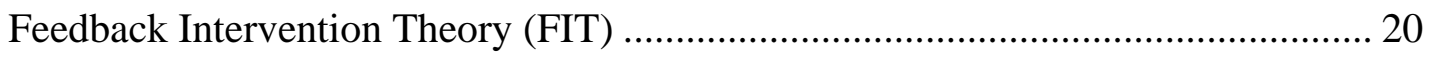

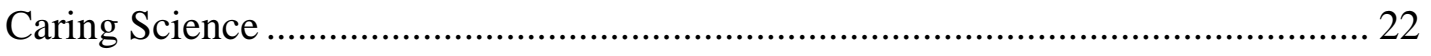

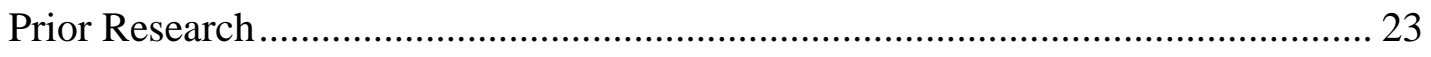

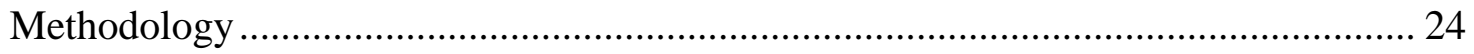

Research Process, Findings, and Discussion ................................................ 28

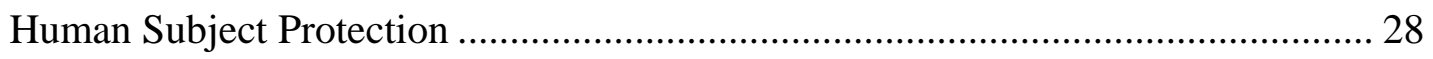

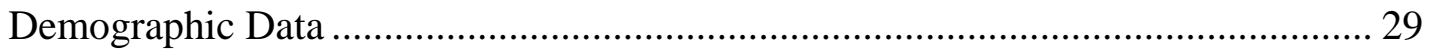

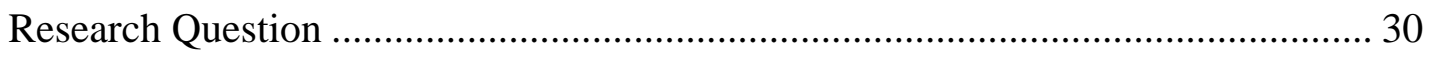

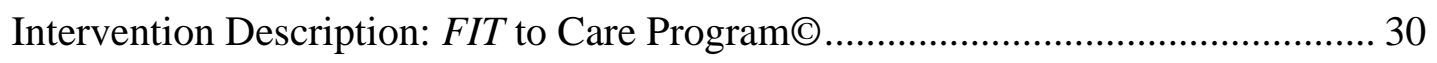

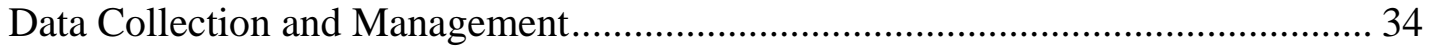


Data Analysis

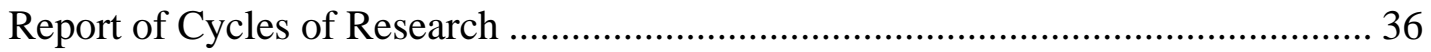

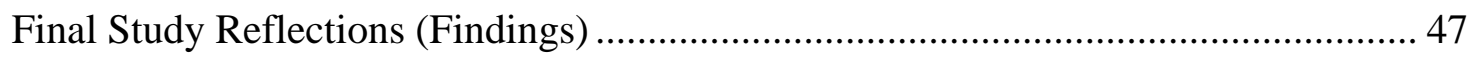

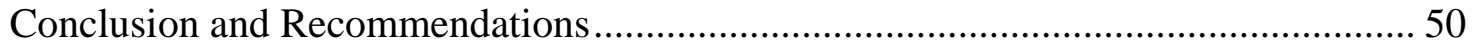

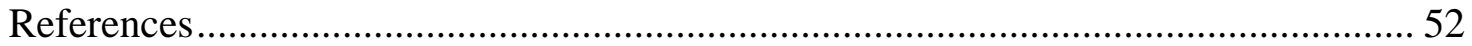

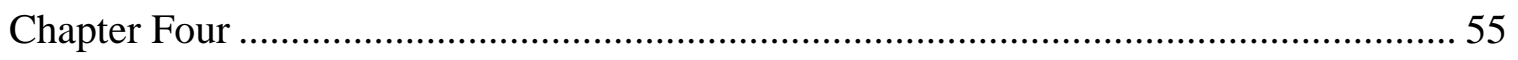

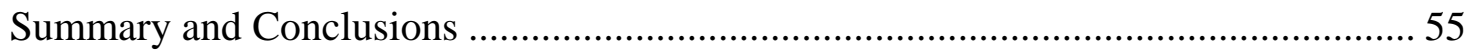

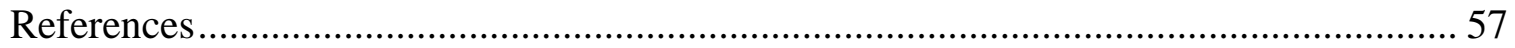

Appendix A: Permissions to Use Published Article .............................................. 59

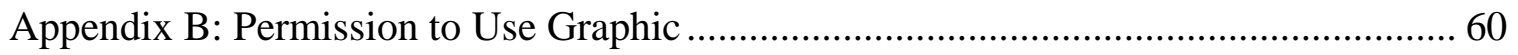

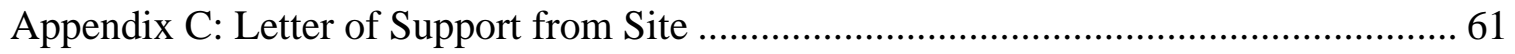

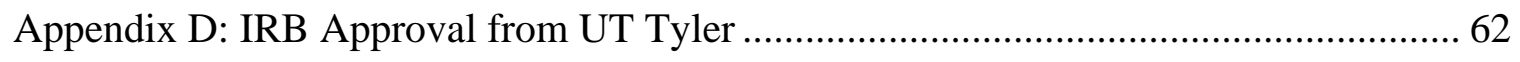

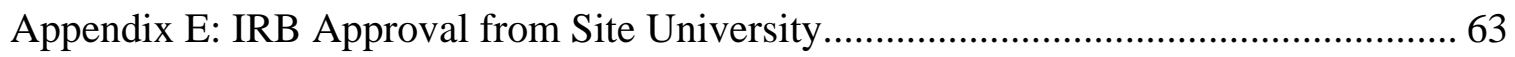

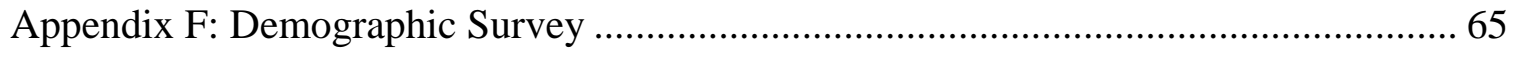




\section{List of Tables}

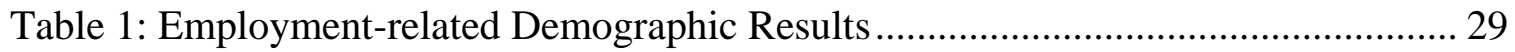

Table 2: FIT to Care $\subset$ Program Guide ............................................................................. 33 


\section{List of Figures}

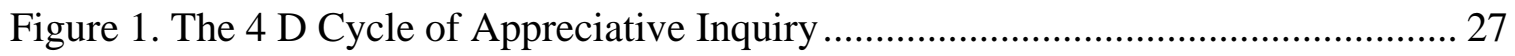

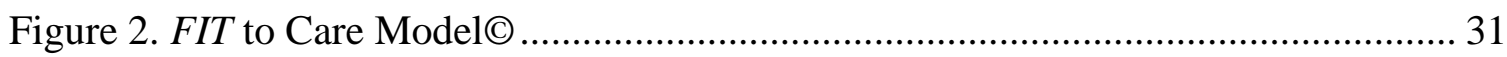




\begin{abstract}
FIT TO CARE: AN ACTION RESEARCH STUDY EXPLORING THE USE OF COMMUNICATION THEORY TO STRENGTHEN CARING RELATIONSHIPS BETWEEN TEACHERS AND STUDENTS
\end{abstract}

\author{
Pamela K. Lake \\ Dissertation Chair: Barbara Haas, $\mathrm{PhD}$ \\ The University of Texas at Tyler
}

May 2013

Watson's Theory of Human Caring lends theoretical structure to nursing curricula grounded in Caring Science. A key principle within the theory is the caring trusting teacher-student relationship. This relationship can be threatened by the need to relay instructional feedback to students when performance has fallen below standards. The tension resulting from this exchange is uncomfortable to all concerned and can damage the relationship and lead to even worse student performance. Nursing literature has not reported studies addressing this problem. Communication studies have extensive reports of such research. Feedback Intervention Theory (FIT) is based on skilled facework to improve student outcomes and protect the caring trusting relationship. This theory had not been applied in a nursing educational setting. The purpose of this action research study was to explore the use of communication techniques based on FIT as a tool for nursing faculty to provide successful instructional feedback while protecting the integrity of the caring-trusting relationship between teacher and student. Study participants reported positive changes in their professional communication related to instructional 
feedback and changed the way such communication is delivered to students so that the culture of caring is supported.

Keywords: caring, communication, Feedback Intervention Theory, nursing education 


\section{Chapter One}

\section{Introduction}

My interest in Watson's Theory of Human Caring began during work toward a Master's in Nursing Education. My thesis was a phenomenological study exploring student nurses' experiences learning the caring process in nursing (Lake, 2005). Much had been written about caring in nursing and I wondered how nursing instructors were teaching caring within a curriculum. My thesis study was set at an ADN program in a community college in East Texas. Nursing students were asked to reflect on what they learned about caring in school and how they learned it. Students described coming into nursing with little understanding of what a caring relationship between nurses and patients should look like. This knowledge developed as they progressed through classes and clinical experiences. The study findings described a transformation that occurs within students as they see caring modeled by mentors and as they listen to stories told by instructors that exemplify caring relationships between nurses and patients. The need for continued studies to better understand this transformation was identified. This research study renewed my personal commitment to incorporate active teaching techniques into my own classes to help facilitate such a caring transformation in nursing students.

I studied with Dr. Jean Watson in Colorado to learn more about Caring Science. In May of 2007 I completed the International Program in Human Caring and Healing. Accepted into the inaugural Caritas Coach Education Program through Watson Caring Science Institute (WCSI), I completed certification in April 2009. I have continued to share research and innovations related to caring science with an international group of committed healthcare professionals. 
In 2008 I began work as a consultant at a university in Oklahoma to help the faculty integrate Human Caring theory into the nursing curriculum. The students and faculty responded positively to the Caring Science programs. At a faculty retreat there we discussed the difficulty of maintaining a caring trusting relationship with students when teachers have to inform students that performances are below expectations. This became the impetus for my research study.

I reviewed literature from communication research seeking an answer to the question of how teachers can give instructional feedback without damaging a caring trusting teacher-student relationship. The results of this study were published in the International Journal for Human Caring (Lake, 2012) and are reported in Chapter Two. Permission to use this published article was granted by the International Association for Human Caring (see Appendix A).

Feedback Intervention Theory (FIT) addresses the problem of how instructional feedback communication can be delivered in a way that will result in positive student outcomes, including both task improvement and student perception of teacher caring (Kerssen-Griep, Hess, \& Trees, 2003; Kerssen-Griep, Trees, \& Hess, 2008; Kluger \& DeNisi, 1996; Trees, Kerssen-Griep, \& Hess, 2009). The faculty group in Oklahoma was receptive to participating in a research study exploring the use of FIT as a tool to help teachers communicate instructional feedback within a caring paradigm. The FIT to Care $\odot$ Program was developed to facilitate structured learning of the principles of the theory and to allow active participation and reflection by each participant. Details of the program are presented in Chapter Three. 
Action research (AR) appeared to be an appropriate methodology for a study in which a group of committed participants search for an answer to a common problem. Research into the methodology supported this belief and the participatory structure and potential for professional and personal growth made AR the ideal selection for this study (Heron, 1996; Herr \& Anderson, 2005; Reason, 1988; Reason \& Bradbury, 2001; Reed, 2007). In the summer of 2012 I studied Collaborative Action Research and Evaluation (CARE) with Marcia Hills (Hills \& Mullett, 2000; Hills \& Mullett, 2005) . Action research was found to be an excellent bridge between research and professional and organizational growth. I believed it would work well with the faculty group in this study. Appreciative Inquiry (AI) is a form of AR that looks at the best a facility has accomplished and moves forward to continue to improve rather than concentrating on problems and deficiencies (Cooperrider, Whitney, \& Stavros, 2008; Whitney \& TrostenBloom, 2003). The 4 D Cycle of AI became the foundation for the model developed for the study. Permission to use the 4D Cycle graphic was granted from the publisher (see Appendix B).

An action research study was proposed to explore the use of communication techniques based on Feedback Intervention Theory as a tool for nursing faculty to provide instructional feedback and yet protect the integrity of the caring-trusting relationship between teacher and student. The university site granted permission to proceed and site administration provided a letter of support for my research study (see Appendix C). IRB approval was gained from both the research university and the site (see Appendices D and E). Informed consent was secured from each participant during 
the first focus group meeting and a Demographic Survey was completed (see Appendix F). The complete report of this research study is presented in Chapter Three. 


\title{
Chapter Two
}

Communication Theory to Facilitate Teacher Caring in Instructional Feedback

Pamela K. Lake

The University of Texas at Tyler

\begin{abstract}
Author Note
Pamela K. Lake, PhDc, $\mathrm{RN}$ is a PhD candidate and Clinical Instructor in the College of Nursing at The University of Texas at Tyler.
\end{abstract}

Correspondence concerning this article should be addressed to Pamela K. Lake, College of Nursing, The University of Texas at Tyler, 3900 University Blvd., Tyler, Texas 75799. E-mail: plake@uttyler.edu Fax: 903-565-5533 Phone: 903-566-7113 


\begin{abstract}
Instructional feedback is a primary component of the teacher-student relationship. Teachers evaluate performances in multiple situations using a wide range of techniques. Evaluation includes feedback related to student performance and identification of areas for improvement to meet standards. These interactions can be a source of tension and stress for both teacher and student, threatening the caring-trusting relationship. Nursing literature has not addressed the use of knowledge from communication research that studies the phenomenon of instructional feedback and develops theories of relevance. This paper explores communication theory as a tool to facilitate caring in teacher-student relationships related to instructional feedback.
\end{abstract}

Key words: Caring, communication, teacher-student relationship, teacher-caring, evaluation, feedback 


\section{Communication Theory to Facilitate Teacher Caring in Instructional Feedback}

Hills and Watson (2011) describe an emancipatory pedagogy for nursing as a foundation for nursing curriculum grounded in the context of Caring Science. One of the basic concepts underlying such a framework is that of relational inquiry. Learning is a process in which teachers and students come together in a caring relationship to co-create knowledge. The learning that can result from these relationships is more than a formal transfer of knowledge from expert to novice; this is transformational learning that has power to change both student and teacher. Four elements are essential for this type of transformational learning to occur; creation of collaborative caring relationships, engagement in critical caring dialogue, reflection-in action, and creation of a culture of caring (Hills \& Watson, 2011). This paper focuses on the creation and maintenance of caring relationships.

Three elements involved in the creation of caring relationships are collaboration, power/empowerment, and participation (Hills \& Watson, 2011). Collaboration brings teachers and students together as partners in the learning process. Power dynamics are important and complex. Equal power is usually not possible in educational settings, particularly in the area of grading. Rather than equal power distribution, teachers can aim for transparency, negotiation, and inclusion of peer and self-critique in the assessment process. Participation involves both commitment and engagement on the part of both 
teacher and student. This paper looks at the second element, power/empowerment, as a source of conflict in the caring relationship, particularly as it relates to grading.

Evaluation of student performance is acknowledged by Hills and Watson (2011) as an intrinsic part of the teaching role. Caring Science values are based strongly on a caring relationship which is equitable and respectful. According to Hills and Watson, grading can be "the most difficult aspect of teaching/learning within a Caring Science paradigm" (p. 274). The integrity of the learning process can be sabotaged by some evaluation procedures. Tension created between teacher and student can threaten the caring relationship, especially if the student performance is below standard/failing. Evaluation strategies to lessen the threat are presented by the authors, but situations will remain in which student performance will require instructional interventions by the teacher.

The nature of teaching requires teachers to point out deficiencies in student performance. Instructional feedback is a primary component of the teacher-student relationship. Teachers evaluate performances in multiple situations using a wide range of techniques. Evaluation includes feedback related to student performance and identification of areas for improvement to meet standards (Hills \& Watson, 2011). These interactions can be a source of tension and stress for both teacher and student, threatening the caring-trusting relationship. The goal is to motivate the student to improve performance, not to shut down communication. 
The threat to the caring teacher-student relationship created when instructional interventions are needed to critique performance below standard can be a problem for teachers. Communication research has studied instructional feedback and developed theories of relevance. This knowledge could inform nursing education related to the problem. Literature from the field of communication related to instructional feedback was searched and the results are presented.

\section{Review of the Literature}

Using Communications \& Mass Media Complete (CMMC) as the search database, original search terms included 'teacher-student communication' and 'communicating failure to students.' These searches resulted in 258 and 318 records respectively. Refining the search to 'instructional feedback' and then to 'feedback interventions' provided 12 interfaces that focused study to the area of interest.

A meta-analysis related to instructional feedback completed by Kluger and DeNisi (1996) found that over one-third of attempted feedback interventions (FIs) reported in the literature resulted in decreased task performance. Their Feedback Intervention Theory (FIT) integrated the research findings suggesting positive interventional feedback strategies. 
Major concepts within the theory include:

- 'Feedback interventions' (FIs) are the "actions taken by an external agent to provide information regarding some aspect(s) of one's task performance” (Kluger \& DeNisi, 1996, p. 255).

- 'Feedback-standard gap' is the gap between observed performance and desired performance (King, Schrodt, \& Weisel, 2009).

- 'Instructional feedback' corresponds to the teacher's communication in order to identify the presence of a feedback-standard gap (King et al., 2009).

- Three levels of linked processes involved in the control of task performance include meta-task processes involving the self, task-motivation processes involving the focal task, and task-learning processes involving the details of the focal task. (Kluger \& DeNisi, 1996).

The central assumption in FIT is that interventions change the focus of attention among the three levels of control (meta-task, task-motivation, and task-learning). Kluger and DeNisi (1996) identified five elements of FIT: (a) behavior is regulated by comparing feedback to goals or standards, (b) goals or standards are ranked by importance, (c) attention is limited and only feedback standard gaps that receive active attention result in behavior regulation, (d) attention is normally directed only toward mid to high ranked goals, and (e) behavior is impacted when FIs result in a change of focus of attention among the levels of control (Kluger \& DeNisi, 1996). 
Teacher caring is a predominant theme found in communication studies, as is the teacherstudent relationship. Teven \&Monte (2008) examined the teacher-caring construct and its correlates. The concepts of respect, trustworthiness, and responsiveness are described as elemental, as well as the importance of a positive environment. Communication studies have found strong links to teacher caring and student learning. A meta-analytical review of 51 studies found that perceived caring was a key dimension in teacher credibility and predictor of student success (Finn et al., 2009). Links to teacher perception of caring were found to positively affect student responsiveness in a correlation study by Malachowski and Martin (2011). Student participation in classroom settings is associated positively with teacher confirmation and caring behavior (Goodboy \& Myers, 2008).

Student sensitivity to feedback was found to be an important factor in how FIs were received and acted on by students (King et al., 2009; Smith \& King, 2004). The first study (Smith \& King, 2004) was a post-test only, experimental study (n=91) to explore how students' sensitivity to feedback impacted performance. King et al. (2009) then developed a feedback orientation scale using a pilot inventory $(\mathrm{n}=245)$ and factor analysis. Of particular importance in these two studies was the claim that feedback cues drawing attention to meta-task processes retard performance, while those focused on task level processes of learning and motivation improve performance (Smith \& King, 2004).

Some background knowledge and definitions are needed to understand communication theories. The term 'face' was introduced in 1967 by Goffman to refer to the desired self- 
image individuals present and defend in interactions with others. 'Facework' relates to strategies used to present, maintain, or restore these preferred identities (Goffman, 1982). Many communication theories related to instructional feedback focus on threats to student face and interventions directed toward mitigation of such threats.

Instructional facework provides a means to respect the desired identity of students while communicating face-threatening messages, such as failure to perform up to standards. Three types of facework described include solidarity, approbation, and tact (KerssenGriep, Hess, \& Trees, 2003). Strategies for solidarity facework include the emphasis of commonalities and expressions of in-group identity. Approbation can be demonstrated by limiting the degree to which the learner's abilities are challenged. Tact strategies show respect for the student's autonomy. Instructional facework has been shown to influence student perceptions of mentorship and of optimal learning environment (Kerssen-Griep, Trees, \& Hess, 2008) and to predict students' perceptions of fairness and usefulness of the feedback (Trees, Kerssen-Griep, \& Hess, 2009). Skilled facework may improve learning by 'keeping students' cognitive energies available to comprehend teacher messages, rather than diverting those limited energies to activate off-task face repair or identity protection processes" (Kluger \& DeNisi, 1996, p. 276). 


\section{Significance}

The review of literature from communication studies shows a significant compatibility between communication theory and Caring Science. Commonalities include acknowledgement of the importance of caring relationships, the imperative to treat others with dignity and respect, the value of an environment that encourages caring relationships, and the belief that caring enhances learning (Hills \& Watson, 2011; Kerssen-Griep et al., 2003; Kerssen-Griep et al., 2008; Trees et al., 2009). The knowledge found in this research can inform nursing knowledge in the area of caring communication and relational caring activities. Instructional feedback carried out with intentional facework skills has been shown to positively impact student learning and perceptions of teacher caring. Research will need to test the impact of instructional facework in a nursing education setting.

\section{Conclusion}

Communication theory has been shown to facilitate teacher caring during instructional feedback in communication settings. The teacher-student relationship is protected when feedback related to performances below standards are presented to students in a way that will protect their identity and focus energy on the task of learning and improving. 


\section{References}

Finn, A. N., Schrodt, P., Witt, P. L., Elledge, N., Jernberg, K. A., \& Larson, L. M. (2009). A meta-analytical review of teacher credibility and its associations with teacher behaviors and student outcomes. Communication Education, 58(4), 516537. doi: 10.1080/03634520903131154

Goffman, E. (1982). Interactional ritual: Essays on face-to-face behavior. New York, NY: Pantheon Books.

Goodboy, A. K., \& Myers, S. A. (2008). The effect of teacher confirmation on student communication and learning outcomes. Communication Education, 57(2), 153179. doi: 10.1080/03634520701787777

Hills, M., \& Watson, J. (2011). Creating a caring curriculum: An emancipatory pedagogy for nursing. New York, NY: Springer Publishing Company.

Kerssen-Griep, J., Hess, J. A., \& Trees, A. R. (2003). Sustaining the desire to learn: Dimensions of perceived instructional facework related to student involvement and motivation to learn. Western Journal of Communication, 67(4), 357-381.

Kerssen-Griep, J., Trees, A. R., \& Hess, J. A. (2008). Attentive facework during instructional feedback: Key to perceiving mentorship and an optimal learning environment. Communication Education, 57(3), 312-332. doi: $10.1080 / 03634520802027347$

King, P. E., Schrodt, P., \& Weisel, J. J. (2009). The instructional feedback orientation scale: Conceptualizing and validating a new measure for assessing perceptions of instructional feedback. Communication Education, 58(2), 235-261. doi: $10.1080 / 03634520802515705$

Kluger, A. N., \& DeNisi, A. (1996). The effects of feedback interventions on performance: A historical review, a meta-analysis, and a preliminary feedback intervention theory. Psychological Bulletin, 119(2), 254-284. doi: 10.1037/00332909.119.2.254

Malachowski, C. C., \& Martin, M. M. (2011). Instructors' perceptions of teaching behaviors, communication apprehension, and student nonverbal responsiveness in the classroom. Communication Research Reports, 28(2), 141-150. doi: 10.1080/08824096.2011.565275

Smith, C. D., \& King, P. E. (2004). Student feedback sensitivity and the efficacy of feedback interventions in public speaking performance improvement. Communication Education, 53(3), 203-216. doi: 10.1080/0363452042000265152 
Teven, J., \& Monte, M. (2008). Teacher caring in the college classroom: A review of the construct and its correlates. Paper presented at the National Communication Association.

http://citation.allacademic.com/meta/p_mla_apa_research_citation/2/5/7/8/9/page s257899/p257899-1.php

Trees, A. R., Kerssen-Griep, J., \& Hess, J. A. (2009). Earning influence by communicating respect: Facework's contributions to effective instructional feedback. Communication Education, 58(3), 397-416. doi:

10.1080/03634520802613419 


\title{
Chapter Three
}

FIT to Care: An Action Research Study Exploring the Use of Communication Theory to Strengthen Caring Relationships between Teachers and Students

\author{
Pamela K. Lake
}

The University of Texas at Tyler 


\begin{abstract}
A caring-trusting relationship between teacher and student is foundational in caring educational environments. This relationship can be threatened when teachers are required to report negative feedback to students who have performed below standards in curricular activities. These interventions can be a source of tension and stress for both teacher and student, threatening the caring-trusting relationship critical to learning. The goal of instructional feedback is to identify discrepancies between the required standard of performance and the student's demonstrated performance, allowing the student to make improvements. Feedback Intervention Theory (FIT) is based on research done in the field of communication. Instructional feedback based on skilled facework has been shown in communication studies to improve students' perceptions of teacher caring and thereby to improve the outcomes of such interventions. The purpose of this action research study was to explore the use of communication techniques based on FIT as a tool for nursing faculty to provide successful instructional feedback while protecting the integrity of the caring-trusting relationship between teacher and student. Study participants reported positive changes in their professional communication related to instructional feedback and changed the way such communication is delivered to students so that the culture of caring is supported.
\end{abstract}

Keywords: caring, communication, Feedback Intervention Theory, nursing education 


\section{FIT to Care: An Action Research Study Exploring the Use of Communication Theory to Strengthen Caring Relationships between Teachers and Students}

A caring-trusting relationship between teacher and student is foundational in caring educational environments. This relationship can be threatened when teachers are required to report negative feedback to students who have performed below standards in curricular activities (Hills \& Watson, 2011). These interventions can be a source of tension and stress for both teacher and student, threatening the caring-trusting relationship critical to learning. The goal of instructional feedback is to identify discrepancies between the required standard of performance and the student's demonstrated performance, allowing the student to make improvements (Kluger \& DeNisi, 1996). Researchers have found that over one third of attempted feedback interventions reported in the literature resulted in decreased task performance (Kluger \& DeNisi, 1996). Research directed toward instructional feedback is called for to improve student performance outcomes and to prevent damage to the caring teacher-student relationship when negative feedback is required.

Lake (2012) found little available research in nursing related to instructional feedback. However, communication studies have explored the topic of instructional feedback and have developed theories related to the subject, such as Feedback Intervention Theory (FIT). FIT has not been tested in a nursing educational setting. The purpose of this action research study was to explore the use of communication techniques based on FIT as a tool for nursing faculty to provide successful instructional feedback 
while protecting the integrity of the caring-trusting relationship between teacher and student.

\section{Context}

\section{Community Context}

This research study took place within a College of Nursing (CON) at a public regional university in Oklahoma. The group was comprised of the entire faculty in the BSN program, which included eleven faculty members at the beginning of the study, including the Chair of the CON. There are three separate campuses, forming a geographic triangle ranging from 65 to 90 miles between sites. The researcher began working with this group in 2008 as a coach and facilitator to help implement Watson's Caring Science theory into the CON curriculum. At the time of the original contact, there were seven faculty. Two participants had joined the program later, one in 2010 and another in 2011. Two new instructors were hired in 2012 as adjunct clinical faculty, bringing the total faculty number to eleven. In action research, the relationship between the researcher and the study participants is referred to as positionality and is an important consideration. This concept will be further described in the Methodology section of this paper. The researcher relationship to this participant group has evolved over time from Outsider to Insider/Collaborator, with the researcher joining in both professional and personal activities and interactions with the faculty.

The current study was envisioned when a group discussion raised the question of how teachers can maintain a caring relationship with students when the teacher role requires critical evaluation of student performance, especially when the student 
performance did not meet standard criteria for success. Participants wondered what evidence is available to help teachers learn to communicate poor performance evaluations to students in a way that would not damage the caring relationship and would lead to positive outcomes. At the request of the group, the researcher agreed to investigate literature in search of an answer to the question. A review of literature from the field of communication identified Feedback Intervention Theory (FIT), which seemed to address the group's concern. At the group's request, the next phase of that on-going process was to explore the use of communication theory to improve teacher caring during student instructional feedback. The group agreed to a participatory action project facilitated by the researcher.

\section{Feedback Intervention Theory (FIT)}

Feedback Intervention Theory (FIT) was developed by Kluger and DeNisi after completing a meta-analysis related to instructional feedback (1996). Major concepts within the theory include:

- Feedback interventions (FIs) are the "actions taken by an external agent to provide information regarding some aspect(s) of one's task performance" (Kluger \& DeNisi, 1996, p. 255).

- Feedback-standard gap is the gap between observed performance and desired performance (King, Schrodt, \& Weisel, 2009).

- Instructional feedback is teacher communication to identify the presence of a feedback-standard gap (King et al., 2009). 
Task performance is controlled by three separate processes, which include metatask processes involving the self, task-motivation processes involving the focal task, and task-learning processes involving the details of the focal task (Kluger \& DeNisi, 1996). The central assumption in FIT is that interventions change the focus of attention among the three levels of control. Five elements of FIT have been identified: behavior is regulated by comparing feedback to goals or standards; goals or standards are ranked by importance; attention is limited and only feedback standard gaps that receive active attention result in behavior regulation; attention is normally directed only toward mid to high ranked goals; and behavior is impacted when FIs result in a change of focus of attention among the levels of control (Kluger \& DeNisi, 1996).

Understanding Feedback Intervention Theory requires some basic knowledge of the concept of facework. The term 'face' was introduced by Goffman in 1967 to describe the desired self-image individuals present and defend in interactions with others. Strategies used by individuals to present, maintain, or restore these preferred identities is referred to as 'facework' (Goffman, 1982).Threats to student face and interventions directed toward mitigation of such threats are the focus of many communication theories related to instructional feedback (Lake, 2012).

Respecting the desired identity of students while communicating face threatening messages, such as failure to perform up to standards, is the basis of instructional facework. Kluger and DeNisi believed that skilled facework may improve learning by 'keeping students' cognitive energies available to comprehend teacher messages, rather than diverting those limited energies to activate off-task face repair or identity protection 
processes" (1996, p. 276). Building on the work of Kluger and DeNisi, three articles published between 2003 and 2009 served as the foundation for the instructional intervention used in this study. Kerssen-Griep, Hess, and Trees described three types of facework, including solidarity, approbation, and tact (2003). Solidarity facework emphasized commonalities between teachers and students and expressions of in-group identity. Approbation is expressed by limiting the degree to which the learner's abilities are challenged, and tact strategies show respect for the student's autonomy. In 2008, the same group of researchers explored how instructional face work has been shown to influence student perceptions of mentorship and of optimal learning environments (Kerssen-Griep, Trees, \& Hess, 2008). In 2009 the study focus was on student perceptions of fairness and usefulness of feedback (Trees, Kerssen-Griep, \& Hess, 2009).

\section{Caring Science}

The philosophical underpinning for this study is grounded in Jean Watson's Theory of Human Caring (Watson, 2008) and in the Caring Curriculum model as described by Hills and Watson (2011). The caring-trusting relationship is foundational in caring science and is seen as a critical part of the teacher-student relationship. According to Hills and Watson, grading can be "the most difficult aspect of teaching/learning within a Caring Science paradigm" (2011, p. 274). Significant compatibility has been found between Caring Science values and those upon which FIT is founded (Lake, 2012). "Commonalities include acknowledgment of the importance of caring relationships, the imperative to treat others with dignity and respect, the value of an environment that encourages caring relationships and the belief that caring enhances learning" (p. 28). 


\section{Prior Research}

Research literature is filled with studies related to the concept of caring in healthcare. A simple search using CINAHL and MEDLINE for "caring" produced over 19,000 studies in the past four years alone. Adding "caring in nursing" reduced the number to 899 and "theory of human caring" resulted in 33 articles between 2009 and 2013. Caring science has become a topic of much interest in nursing and nursing research as the profession moves forward in the $21^{\text {st }}$ century. Jean Watson has recognized this "awakening to the essence or core of human caring" as professional maturing and evolution to a higher consciousness (Clarke, Watson, \& Brewer, 2009, p. 339). Magnet hospital initiatives have contributed to an increase in caring theory guided practices, as has the work being done by the Watson Caring Science Institute and the International Caritas Consortium. Research studies using Watson's theory include studies for development of models in Caring Leadership (Williams, McDowell, \& Kautz, 2011), proposals for nurturing nursing students during clinical rotations (Goldin \& Kautz, 2010), strategies to address bullying within the nursing profession (Broome \& Williams-Evans, 2011), and many more areas of interest in various nursing settings and with different populations. Caring communication studies are not as prevalent in nursing literature. Sumner (2012) proposed bi-directional communication as a moral construct of caring in

nursing. Role-play was used to teach caring communication in a study based on palliative care settings (Betcher, 2010). Communication studies exploring instructional interventions between teachers and students in nursing programs were limited. A study from the UK explored reluctance of clinical mentors to fail underperforming students, 
finding that providing critical feedback was often avoided or down-played due to mentor discomfort (Heaslip \& Scammell, 2012). The authors recognized the need for students to receive honest instructional feedback, but did not address how mentors could learn to provide that need. No other studies in nursing were found related specifically to caring communication in teacher-student relationships that require instructional feedback.

Communication literature has extensively explored caring communication in educational settings. Teven and Monte (2008) explored the evolution of the teachercaring construct and traced its importance in instructional communication and educational research. Strong links to teacher caring and student learning were reported. Perceived caring was found to be a key dimension in teacher credibility and a predictor of student success (Finn et al., 2009). Teacher caring behavior was found to be positively associated with learning outcomes and student communication in a classroom setting (Goodboy \& Myers, 2008; Malachowski \& Martin, 2011). Student sensitivity to Feedback Interventions (FI) was explored and a student orientation scale developed to address individual student needs related to feedback (King et al., 2009; Smith \& King, 2004). No studies were identified that used FIT as a theoretical foundation embedded in a Caring Science philosophy in nursing.

\section{Methodology}

Action Research (AR) differs from quantitative or qualitative research methodologies in several important ways. First, the participatory nature of AR requires that participants are either in control of the research or participate in the research design and methodologies. Second, the purpose of an AR study includes personal and 
professional growth, as well as organizational and professional empowerment. Power relations provide a third difference. Control rests in the hands of participants rather than with the researcher, who may be an equal participant or an outside consultant/observer. Finally, action is central to the study (Herr \& Anderson, 2005). While definitions of AR vary relative to specific methodologies, the study is done "by or with participants" and "never to or on subjects" (p. 3). Research is collaborative and evidence is required to support assertions. The research setting is naturalistic and reflects society that is characterized by conflicting values and unequal distribution of resources and power (Herr \& Anderson, 2005).

The participatory nature of action research creates unique sampling guidelines. As an outsider in collaboration with insiders, the researcher is invited to work within an existing group to provide specific expertise to improve quality/performance in a specific area defined by the group (Herr \& Anderson, 2005). Recruitment is not a part of this process; rather the disclosure of how entry into the group was facilitated.

Knowledge generated in AR is most importantly meant to be fed back into the local setting. This local knowledge is often shared with an immediate community of practitioners, but is not always meant to be generalized (Herr \& Anderson, 2005). This can be a threat to external validity and the researcher wanting to use findings for public knowledge must negotiate with participants in advance. Transferability can be established using a case study approach, by new theory generation, or by the development of products or instruments based on study findings. Publication of the proposed research as 
a case study will contribute to transferability and demonstrate the use of AR as a valid research methodology for nursing.

The concept of positionality is unique in AR and is critical to consider for research ethics and for research validity. The researcher's role in the AR study falls along a continuum from one of insider to a position as outsider. Six possibilities include; Insider, Insider in collaboration with other Insiders, Insider in collaboration with Outsider(s), Reciprocal collaboration (Insider-Outsider teams), Outsider(s) in collaboration with Insider(s), and Outsider(s) studies Insider(s) (Herr \& Anderson, 2005). Stakeholders will need to negotiate what expectations they have for the research. While the role is not static, the researcher is obligated to interrogate the multiple positionalities manifest during study evolution to be aware of the impact on the study. When a true partnership develops, the AR researcher moves toward an insider perspective (Herr \& Anderson, 2005). Applied research would identify this as a serious threat to study validity, while AR accepts it as a key process in participatory research.

Action research demands some form of action or intervention, which can be described as a spiral or cycle, consisting of the development of a plan of action, action to implement the plan, observation of the effects of action, and reflection on results as the basis for further action (Herr \& Anderson, 2005). This cycle is iterative and often has no easily identified beginning or end. The collaborative nature of AR demands the active participation of group members in each step of this process.

Evolving methodology is inherent in AR, as the iterative cycles spiral in a continuous pattern. Appreciative Inquiry (AI) is a form of Action Research based on the 
assumption that every organization has something that works well, and those strengths can be the starting point for creating positive change (Cooperrider, Whitney, \& Stavros, 2008). The four phases of the AI cycle are Discover, Dream, Design, and Destiny. In the Discovery phase, the group is asked to identify "what gives life" to the organization and to appreciate "the best of what is" (p. 43). In the Dream phase, the question asked is "what might be" (p. 44). The Design phase is for construction of the future design, and Destiny is the time to reflect on what has been accomplished and where the next step will lead (pp. 45-47). The 4 D Cycle was used to guide participants through this research project. (Figure 1)

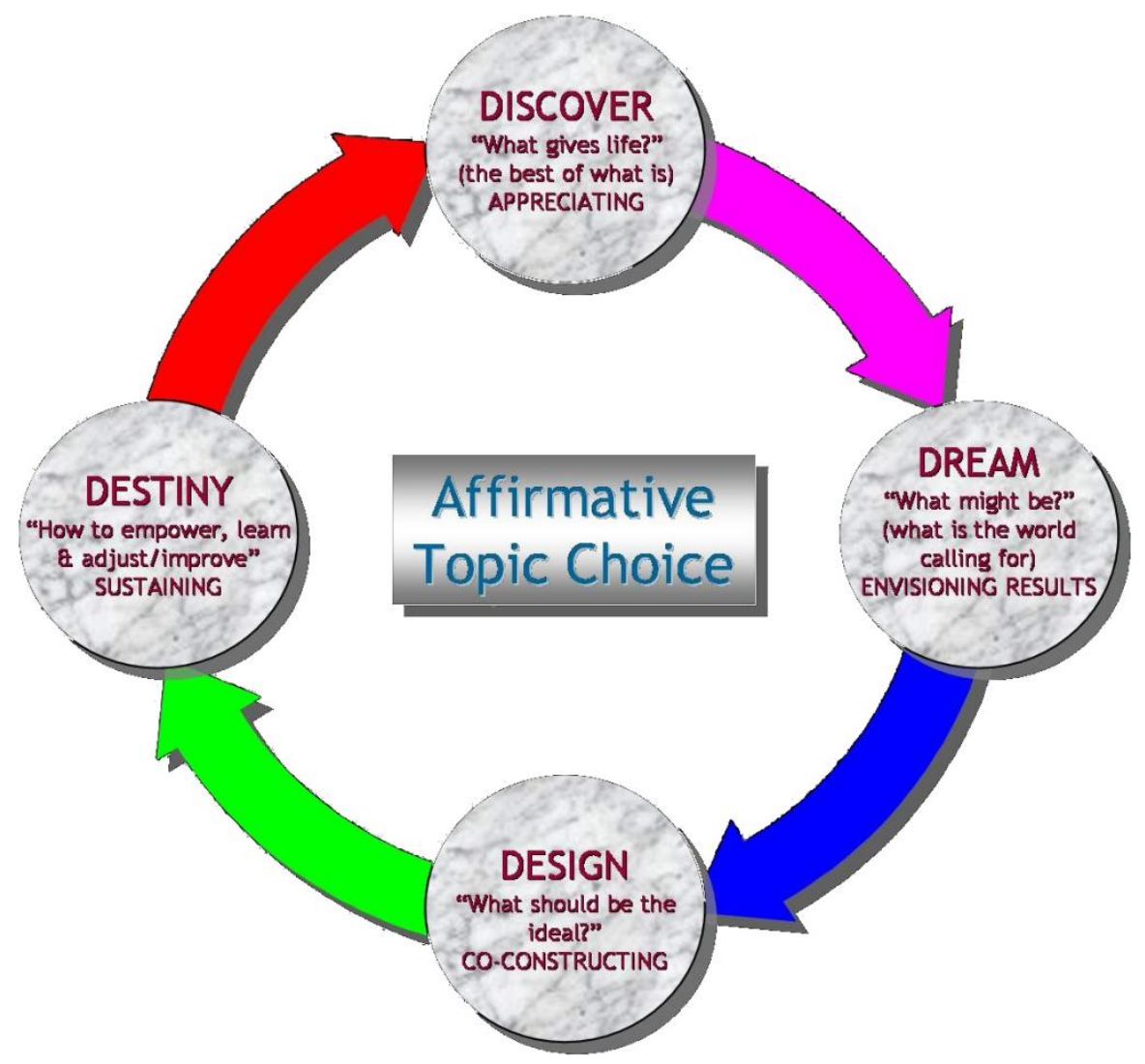

Figure 1. The 4 D Cycle of Appreciative Inquiry

(Graphic used with permission from Cooperrider, Whitney, \& Stavros, 2008) 
Participants must be included in all design and methodology decisions for process validity (reflective cycles and relationship with participants) and democratic validity (ethics and social justice) (Herr \& Anderson, 2005). The research proposal is the researchers' "best guess as to what will happen in the field" (p. 76). Anticipating the direction the research might take, the design is based on the ongoing cycles of action research.

Action research is often done by researchers with an ongoing relationship to the group participants. This historical relationship affects the positionality of the researcher as well as allowing for prior knowledge related to the reason for the study. Herr and Anderson (2005) refer to this as piloting, and encourage it as a means of setting the stage for the actual study.

AR was an appropriate study design for this study because of the participatory nature of the inquiry group and because of the group desire to make changes on both professional and personal levels as a result of the process. Participants identified a threat to the caring teacher-student relationship when teachers have to communicate poor performance to students. They also verbalized a desire to learn communication techniques to guide them toward strengthening the culture of caring within the CON at their university.

\section{Research Process, Findings, and Discussion}

\section{Human Subject Protection}

IRB approval from both the researcher's university and the site university was gained prior to beginning this study. Administration at the university was supportive of 
this study. Written informed consent was obtained from all participants. Confidentiality was negotiated within the group. At their discretion, raw information was not shared with all members, and only de-identified data was available to the group. Permission to publish research findings was granted by the group prior to beginning the study.

\section{Demographic Data}

As an action research (AR) study, the sample is based upon membership in the group of participants and is a number that cannot be manipulated by the researcher. In the first meeting of the research group, newly hired faculty members were identified and given background information to help them understand the evolution of the current study. During the study, one of the new faculty members declined to participate in the study, leaving ten participants at the start of the project. Demographic data was collected through a Faculty Demographic Survey completed by participants at the first focus group The inquiry group consisted of ten white/Caucasian, non-Hispanic females between the ages of 26 and 65. The mean age was 50.9 years. (See Table 1 for employment-related demographic results.)

\section{Table 1}

\section{Employment-related Demographic Results}

Variable

Rank

Clinical Faculty/ Lecturer

Associate Professor

Professor

Other
10

6

1

1

2

Continued on next page 
Table 1 (Continued)

Employment Status

Full-time 9

Part-time 1

Education

Bachelor's degree 2

Master's degree 6

Doctoral degree 2

Years Teaching Experience

$<1$

$1-5$

6-10

$11-15$

$16-20$

$>20$

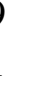

2
6
2

2


Design, and Destiny), the "FIT (Feedback Intervention Theory) to Care" intervention developed for this study is illustrated in Figure 2. The spiral of AR corresponds to the inquiry groups' journey to integrate Watson's Theory of Caring Science, founded on the ten Caritas Processes, into the curriculum at the CON (Watson, 2008). Four individual cycles were based on the four focus group meetings planned for the study.

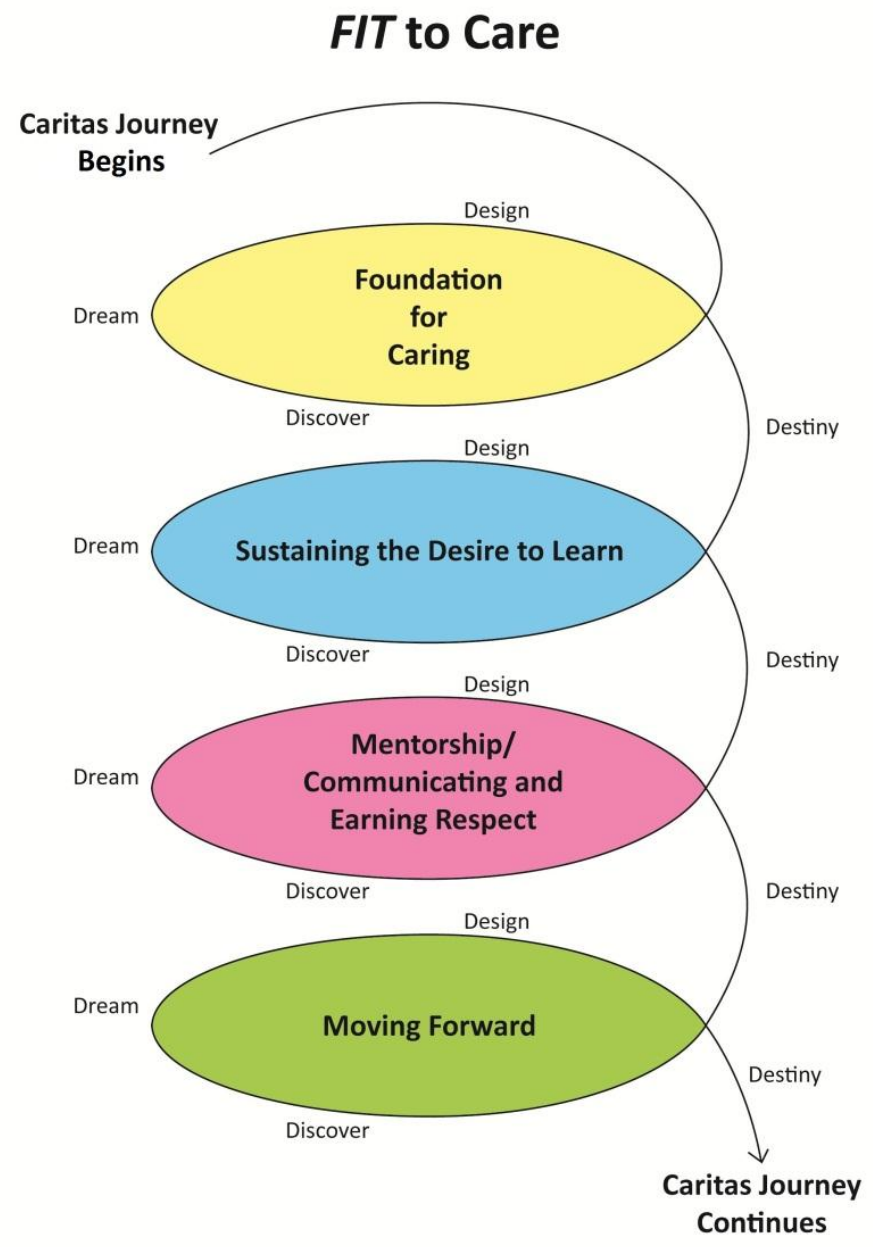

Figure 2. FIT to Care Model () 
The FIT to Care Program involved three individual modules, each with a reading assignment, a theoretical content area in the form of an electronically recorded presentation developed by the researcher, assigned exercises, and a reflective journal template. These were kept brief and concise to decrease research participant burden and allow busy faculty to complete them in a timely manner. FIT to Care Program modules were made available to the participants via Blackboard at the beginning of three consecutive months with reflective journals due by the end of each month. Reflective journaling was used to describe individual experiences and reactions to the FIT strategy. The themes of the three FIT to Care Program modules were:

1. Sustaining the Desire to Learn: The Dimensions of Instructional Facework

2. Mentorship and Optimal Learning Environments: Attentive Facework and Wise Criticism

3. Communicating and Earning Respect: Quality and Usefulness of Feedback (Fair and Useful)

A brief synopsis of modules based on the FIT to Care Program designed by the researcher was presented at the initial focus group. See Table 2. 
Table 2

FIT to Care@ Program Guide

\begin{tabular}{|c|c|c|c|}
\hline & $\begin{array}{c}\text { FIT to Care } \\
\text { Module\#1 }\end{array}$ & $\begin{array}{l}\text { FIT to Care } \\
\text { Module\#2 }\end{array}$ & $\begin{array}{c}\text { FIT to Care } \\
\text { Module\#3 }\end{array}$ \\
\hline $\begin{array}{l}\text { Date } \\
\text { available }\end{array}$ & Beginning Month \#1 & Beginning Month \#2 & Beginning Month \#3 \\
\hline Theme & $\begin{array}{l}\text { Sustaining the Desire } \\
\text { to Learn }\end{array}$ & $\begin{array}{l}\text { Mentorship \& } \\
\text { Learning } \\
\text { Environments }\end{array}$ & $\begin{array}{l}\text { Communicating } \\
\text { Respect }\end{array}$ \\
\hline $\begin{array}{l}\text { Research } \\
\text { Article }\end{array}$ & $\begin{array}{l}\text { Kerssen-Griep, J., } \\
\text { Hess, J. A., \& Trees, } \\
\text { A. R. (2003). } \\
\text { Sustaining the desire } \\
\text { to learn: Dimensions } \\
\text { of perceived } \\
\text { instructional facework } \\
\text { related to student } \\
\text { involvement and } \\
\text { motivation to learn. } \\
\text { Western Journal of } \\
\text { Communication, } \\
\text { 67(4), 357-381. }\end{array}$ & $\begin{array}{l}\text { Kerssen-Griep, J., } \\
\text { Trees, A. R., \& Hess, } \\
\text { J. A. (2008). } \\
\text { Attentive facework } \\
\text { during instructional } \\
\text { feedback: Key to } \\
\text { perceiving } \\
\text { mentorship and an } \\
\text { optimal learning } \\
\text { environment. } \\
\text { Communication } \\
\text { Education, 57(3), } \\
\text { 312-332. }\end{array}$ & $\begin{array}{l}\text { Trees, A. R., Kerssen- } \\
\text { Griep, J., \& Hess, J. } \\
\text { A. (2009). Earning } \\
\text { influence by } \\
\text { communicating } \\
\text { respect: Facework's } \\
\text { contributions to } \\
\text { effective instructional } \\
\text { feedback. } \\
\text { Communication } \\
\text { Education, 58(3), 397- } \\
416 .\end{array}$ \\
\hline $\begin{array}{l}\text { Caritas } \\
\text { Connection }\end{array}$ & $\begin{array}{l}\text { Hills, M., \& Watson, } \\
\text { J. (2011). Creating a } \\
\text { caring curriculum: An } \\
\text { emancipatory } \\
\text { pedagogy for nursing. } \\
\text { New York, NY: } \\
\text { Springer Publishing } \\
\text { Company. } \\
\text { Chapters } 3 \text { and } 4\end{array}$ & $\begin{array}{l}\text { Hills, M., \& Watson, } \\
\text { J. (2011). Creating a } \\
\text { caring curriculum: } \\
\text { An emancipatory } \\
\text { pedagogy for } \\
\text { nursing. New York, } \\
\text { NY: Springer } \\
\text { Publishing } \\
\text { Company. } \\
\text { Chapter } 5\end{array}$ & $\begin{array}{l}\text { Hills, M., \& Watson, J. } \\
\text { (2011). Creating a } \\
\text { caring curriculum: An } \\
\text { emancipatory } \\
\text { pedagogy for nursing. } \\
\text { New York, NY: } \\
\text { Springer Publishing } \\
\text { Company. } \\
\text { Chapters } 6 \text { and } 7\end{array}$ \\
\hline $\begin{array}{l}\text { Presentation } \\
\text { Format }\end{array}$ & Power Point & Power Point & Power Point \\
\hline $\begin{array}{l}\text { Exercise/ } \\
\text { Practice }\end{array}$ & Role play & Role play & Role play \\
\hline $\begin{array}{l}\text { Reflective } \\
\text { Journal }\end{array}$ & Template & Template & Template \\
\hline Journal due & End Month \#1 & End Month \#2 & End Month \#3 \\
\hline
\end{tabular}


Rather than being a linear process, AR becomes a dance in which planning, action, observation, and reflection build upon one another and move in and out of the spiral in a fluid and responsive motion. The process is emergent and can only proceed correctly if participants are given freedom to dance to their own music, and the researcher acts as an Outsider observer or an Insider participant to facilitate discovery (Hills \& Mullett, 2000). The tentative plan for the research study as it was proposed was reviewed and approved by participants. The reality as it unfolded over the weeks and months of the study demonstrate the emergent nature of AR and the need for the researcher to remain flexible and open to the possibilities of allowing the process to evolve.

\section{Data Collection and Management}

Data collection was negotiated with the research study participants as required by the AR process. Five focus group meetings were recorded using digital recording equipment, providing an auditory record that was transcribed by the researcher. Field notes were written during the meetings by the researcher and written or recorded reflections were created by the researcher throughout the study. FIT to Care program content was made available to faculty via Blackboard technology, a web based learning system available at the researcher's institution. Reflective journals were submitted by participants via the secure Blackboard website program and were accessible only to the researcher. All recorded, written, printed, or transcribed data identifying participants was securely maintained and accessible only to the researcher.

While documentation is the property of the group, negotiation at the beginning of the study allowed the researcher to maintain the data to meet IRB requirements. 
Participants were given access to de-identified data during the data analysis process. Data to be submitted for publication was reviewed by the group during the final focus group and permission granted.

\section{Data Analysis}

Data analysis began immediately at the first focus group meeting and continued as data became available from each focus group and from reflective journals. AR demands collective analysis of the data to challenge the perspectives of each participant and to lead to outcomes reflective of each one (Hills \& Mullett, 2005). Participants were included in the process at all stages by the reflections recorded in monthly journals and more formally during the focus groups as they occurred. Data was collected from audio recordings of all focus groups, reflective journals submitted electronically by participants, and field notes and reflections recorded by the researcher. Data was transcribed by the researcher into a de-identified written text that finally contained 114 pages of single spaced data. This data was reviewed and analyzed by the researcher and participants in an attempt to reflect on its overall meaning.

A primary goal of data analysis is to reduce and interpret the meanings of collected data and to confirm the accuracy through dialogue with participants (Cooperrider et al., 2008). Sense-making is an umbrella term describing the way individuals attempt to find meaning from conversations and experiences in the world. In research, this refers to making sense of the themes and patterns discovered in data collected from interviews, focus groups, and narratives. The data can be organized in tables, graphs, pictures, or any creative strategy that helps the researcher understand what 
is being said from multiple perspectives and to identify common threads or anomalies. The focus is on meaning of the data.

Specific steps for data analysis followed the recommendations of Creswell (2007). The researcher created and organized files for data in terms of chronological order and setting, then read and re-read the transcripts and notes, searching for understanding. Notes were made and initial codes formulated, then data was analyzed for themes and regularly occurring patterns. ATLAS.ti software provided the means to assign codes and organize codes into families, maximizing efficiency and reliability. These themes were verified by participants during focus groups.

Heron (1996) says "the challenge after positivism is to redefine truth and validity in ways that honor the generative, creative role of the human mind in all forms of knowing" (p. 13). In this study, process validity was enhanced by close attention to the iterative process of AR and by multiple perspectives, or triangulation, resulting from use of more than one method of data collection (focus groups, reflective journals, and field notes). Outcome validity or trustworthiness, is a product of researcher integrity and credibility and is manifest in successful outcomes seen in action that lead to resolution of the problem (Herr \& Anderson, 2005).

\section{Report of Cycles of Research}

\section{Focus Group \#1.}

Focus Group \#1 began with a review of the journey the CON began in 2008 when they chose to integrate caring into their curriculum using Watson Caring Science as the theoretical foundation. Group members were asked to reflect on what this process has 
been like for the organization and for them as individual teachers. What gives life to this organization today? What is the best of what a caring foundation has meant to the CON here? Participants shared memories of their introduction to Watson's Theory of Human Caring and their creation of a conceptual framework model to represent the vision of how those values would become the foundation of their curriculum. They proudly recalled working to integrate that model into each individual course syllabus and placing framed copies throughout the nursing buildings on each of the three campuses. One group member said, "I learned a different way of caring." This culture of caring was reflected in teacher-student relationships as well as teacher-teacher, student-teacher, and studentstudent relationships. The group acknowledged areas of concern, particularly related to formal meetings between teachers and students when issues of student performance have reached a level of seriousness that could impact student continuation in the program. Overall, they voiced a feeling of being "on the right tract." When asked for one word that summed up the current status of the program, responses included "supported," "family," "welcoming," "forgiving," "trusting," and "mentoring."

The group was then asked to focus on the future as the Dream phase of the cycle began. This is a time to envision the best possibilities that incorporating caring into teacher-student communication during instructional feedback might produce. What would it look like for faculty to communicate with students using instructional feedback grounded in a caring relationship? What is your highest hope for caring communication between teachers and students in the future of the CON at this university? Faculty envisioned teacher-student interventions that were founded in mutual understanding and 
led to student growth and improved performance. They voiced a desire to move away from a "them vs. us mentality" and toward a partnership with students and a "student centered approach" to learning. They wanted to eliminate procedures that left students feeling "ganged-up on" by faculty. Caring environment was recognized as an important part of the communication process and participants wanted to be sure the student was in a non-threatening atmosphere.

Participants co-constructed a method for achieving the Dream by accepting a tentative plan for an intervention strategy presented by the researcher, grounded in communication techniques based on Feedback Intervention Theory (FIT). This facilitated the action or Design cycle of the AR process as the first focus meeting came to a close.

\section{Reflections.}

Field notes recorded by the researcher after the meeting identified two areas of concern. First, the focus group meetings were set up to meet during the monthly faculty meetings because all faculty are already scheduled to be on one campus. This led to timing concerns that left the focus group meeting being rushed and fragmented as we had to work around other activities scheduled for the beginning of the semester. Power relations are important in AR, and it was difficult to move in and out of faculty meetings in which members have specific roles and hierarchy structure, then into a group in which those boundaries disappear. The second challenge related to the AR process. As a group Insider, it was difficult to stay on task without slipping into personal conversations with other participants. The participatory nature of this methodology left me feeling conflicted between a role as "just a member of the group" and a need to take charge of some of the 
process to facilitate structure and progress. As I transcribed data from the first group meeting, I was struck by how much of my own voice was being transcribed. Some of this can be explained by the need for informed consents and explaining the FIT to Care program in this first group meeting, but I felt it was a significant observation.

\section{Focus Group \#2.}

Focus Group \#2 met one month later. The purpose of this meeting was to reflect on the findings from the first FIT to Care Program module (Sustaining the Desire to Learn) and to begin to analyze data that was transcribed from Focus Group \#1. The group was to consider any possible changes in the study design or methods needed or desired, and plan to continue forward. As stated, action research methods are emergent and must be reflective of group participation at all steps of the process.

About two weeks after the first focus group, the CON Chair left unexpectedly due to unanticipated personal issues that were not made known to the faculty or students. An Interim Chair was appointed from the group and everyone was struggling to keep the program running while grieving for the loss of their leader, colleague, and friend. This unpredictable event had a predictably disruptive effect on the study process.

The second focus group began with the process of Discovery. The group shared feelings of loss, abandonment, anger, and anxiety. They felt overwhelmed by added responsibilities and the chaos created by loss of strong leadership. The students were struggling with similar feelings and did not believe the faculty was being honest when they said they did not know why the Chair had left. The faculty questioned whether administration was being honest with them. A participant wrote in her journal, "I had the 
thought that we are currently working through the process of hearing bad news and having to give bad news to our students. It seems like I have to separate from my own personal grief to be able to be more focused and caring with students." Trying to find the best of what was happening was a challenge, but the group was encouraged to recognize their own strengths and talents and to pull together as a group. They recognized strong group connections and remembered they had worked together to make the program what it is today. They became united in a desire to move forward with a renewed sense of empowerment.

The Dream phase began with the group re-focusing and looking to a new future. They committed to continue to support the culture of caring at the $\mathrm{CON}$ and to complete this AR study exploring communication techniques that will sustain that dream. They felt they wanted to work together to begin healing the caring-trusting relationships between teachers and students and also between teachers and administration. They envisioned relationships that were open and honest and comfortable for both parties.

The participants expressed feeling overwhelmed by the amount of reading and writing required by the study design. Few had been able to begin the first module (readings, slide presentation, Discussion Board, electronic journal) and no journals had been submitted at the time of this meeting. A folder was prepared by the researcher for each group member with copies of all the readings from the FIT to Care Program, hoping it would help reduce the effort required to complete modules. Participants seemed more dismayed, fearing it was too much to do on top of heavy workloads and new responsibilities. After group discussion, the Design phase resulted in a new plan that 
eliminated the Blackboard modules completely and left only the monthly readings and electronic journal submission. The group expressed interest in an idea to develop Wiki pages related to the FIT to Care content, and that was made available on the Blackboard site as an experiment. The next focus group was scheduled to meet in two months.

\section{Reflections.}

In my field notes after the second group meeting, I expressed personal disappointment that the FIT to Care Program failed to be utilized as designed, and lamented my hard work setting up the Blackboard modules. I had to bear in mind the process of AR that allows the design to emerge as the study progresses. The proposal of the study is only a best guess as to what you expect to happen, which is compared to "designing the plane while flying it" (Herr \& Anderson, 2005, p. 69). I wondered if the study would actually help the group to move through this difficult time by studying caring relationships and caring communication. And I wondered if participants would be able to engage actively in the study as they had hoped to before the chaos began.

Field notes recorded two weeks after Focus Group \#2 state “participants aren’t participating!" I noted that only 2 journals had been submitted and no one had been onto the wiki site I had opened, complete with a video tutorial. "I am not doing enough to encourage participation" I wrote, and planned to send out weekly emails reminding participants to complete readings and submit journals. I planned to send links to the wiki site. I considered finding incentives for participation. Two weeks later I reported a slight increased participation in response to my emails, but data submission was still low. In a conversation with a colleague, I bemoaned the poor participation and relayed what I had 
done to encourage more input from the group. She gently reminded me of the Caring Science foundation of this study and the caring communication focus, and said, "You have become your own negative case." Her comment was insightful. Not only was I not being true to the philosophy and theory, I was not allowing the AR process to unfold as it should. I re-focused and planned to make another trip to Oklahoma in one week for an unscheduled Focus Group meeting. I resolved to be open to the direction the AR moves and to utilize the principles of Caring Science and FIT to communicate caring and solidarity during the meeting.

\section{Focus Group \#3.}

This extra Focus Group was scheduled as a means of data collection to provide participant input that had not been forthcoming in the electronic format of the study (electronic journals and a wiki page). Without prelude the group was asked to share what they were learning in the study. The discussion was animated and all members participated openly. No attempts were made by the researcher to guide the discussion in any particular direction. Members shared from the study readings and from personal experiences as teachers and as students themselves. Topics covered teacher-student relationships, caring communication, traditions in nursing education, generational differences, and new teaching challenges with online classes and distance learning via interactive tv. This became an exercise in Discovery as participants were given the opportunity to speak as experts. All ways of knowing were honored. We had to pause for lunch at this point in the meeting. 
We returned after lunch and met informally in a busy office with activity that often made conversation difficult. Data analysis (part of Discovery) was accomplished by reviewing the data available so far. The group stated that they believe they are learning through the process. As one participant said, "It's not taking a picture of a particular time, it's the ongoing process, so that we work through and come around full circle, and if there is still a problem, we do this. It is a continuing spiral.” Participants asked questions about how to access the wiki page and we were able to demonstrate on one of the office computers. The Design for the next month was to continue with readings, journals, and wiki page development. The next focus group was scheduled to meet in one month.

Seven journals were submitted during the month. Most of the information from journals was shared during the Focus Group by its author. Sometimes the researcher introduced a topic without revealing the source and allowed the group to comment on it. In this way the participatory AR process was allowed to unfold and the group shared the entire experience. Confidentiality was carefully maintained and no identifiable information from journals was ever shared with the group by the researcher.

\section{Reflections.}

I reflected in field notes how hard it was not to organize an outline for the group meeting. Even in the moments before the meeting began, I had to resist the urge to jot down just a few guidelines to "keep us on track." Once again I felt conflict resulting from positionality within the group. As an Insider, I should have a voice; but if I try to exert power using my role as researcher or facilitator to control the direction the study takes, I jeopardize process validity. I wrote, "Let the process be the process!" It was a difficult 
balance. In this meeting, surrendering control allowed all participants to speak their truth. When I had set myself up as an expert, fewer members were willing to speak freely. More data was generated during the first 46 minutes of Focus Group \#3 than was available from the first two months of the study combined.

\section{Focus Group \#4.}

This Focus Group was originally scheduled with the goal of reflecting on journals and feedback from FIT to Care Program modules two and three (Mentorship and Optimal Learning Environments, and Communicating and Earning Respect) and to continue analysis of all data collected. Participants were provided two copies of all the deidentified data transcribed from three focus group recordings, 17 journals, all field notes, Blackboard Discussions and the wiki pages, amounting to over 90 pages in one single spaced document. An offer was made by the researcher to post this document on the group's secure Blackboard site for later participant review, but no one felt that necessary. The Discovery phase began as data was presented chronologically in summary form by the researcher, while the group listened and commented as themes and patterns were identified. There was a sense of group pride and accomplishment as they recognized the work they have done in this study. Participants reflected on the loss of past leadership and feeling conflicted about changes needed as they move forward without her. They were united in the Dream of providing caring communication related to instructional feedback for students and agreed to continue to work toward that vision.

The group recognized personal and group growth that has already resulted in changes within the program. They reflected on how these changes have resulted in 
different communication with students at many levels, including one-on-one interactions in classes and in clinical settings, and on a higher level when students need to come into their offices for more formal instructional interventions. They described thinking before they speak, focusing on the task at hand, making sure the student understands why they need the intervention, and listening to the student's voice and ideas about how to improve rather than just 'handing out advice." Faculty meetings have been changed and better reflect an attitude of caring and student centered agendas. Many examples were given by participants of how FIT has been incorporated into student interactions, and the group agreed this has helped them feel like they were being more caring in teacher-student relationships. They also said this AR process had improved solidarity among the faculty group as they learned more about each other and pulled together for a common goal. The meeting ended with the next group meeting scheduled in one month.

\section{Reflections.}

The meeting was scheduled on the same day as end of semester meetings and parties. The group met in the home of one of the participants and just before a holiday meal and a gift exchange were planned. The tone was festive and I found it difficult to maintain group focus on the study and data analysis. I began with a moment of quiet meditation and soft music from a singing bowl, a technique I have used with this group before. I then summarized the data set and asked for group input as themes and patterns were identified and discussed. Overall, the group expressed pride at their accomplishment as they reviewed the events of the past months. Group unity and shared goals for the future were apparent. Change had already occurred and strong commitment was 
expressed to continue to work toward realizing a Destiny that will sustain their Dream. The process was working as we used the AR process to learn. The process was the intervention! The FIT to Care Program was a means to follow the process through Design.

\section{Focus Group \#5.}

The final focus group meeting was scheduled to review findings compiled by the researcher based on all data collected and all participant feedback. This step is vital to AR process validity, and participants' voices were reflected in the final assessment of study findings. After a brief review of the findings that were summarized from Focus Group \#4, the group agreed with the study findings as they were presented. Participants reflected on what the process has meant to them and decided on the next focus for continuation of their Caritas Journey. The readings associated with the FIT to Care Program were described as too much or too difficult by most participants. One person expressed that after the CON Chair left unexpectedly, the group was overwhelmed and "emotionally there was just not a lot of energy that could be directed at this project." One member said the readings were necessary to learn about the FIT process, and she especially enjoyed the readings from Hills and Watson (2011) that tied it all together for her. Each participant agreed that they had learned and changed because of the study. Comments include the following:

- "I think about it now every time I talk to a student, about how I am coming across to them."

- "I found out a lot about myself." 
- "This has opened up new areas for me."

- "I really enjoyed the action research approach. I liked seeing different perspectives than just my own."

- "It has made me more conscious of what I am saying and how I am saying it."

- "I didn't have time to read everything, but I learned from the group."

Moving to Destiny, the group was asked how they would sustain the commitment to caring communication in teacher-student instructional feedback. They discussed the possibility of adding caring to the student evaluation of faculty forms. Another suggestion was to add caring to each monthly faculty meeting agenda so they will continue to talk about it at least once a month. The final group meeting ended with thanks for all participation.

\section{Reflections.}

The data collection and data analysis was completed and all that remained was the written report. The study resulted in change, as is the purpose of AR. I believe it also led to emancipatory power as the group came together and realized their own strength and embraced the challenge of continuing without the leader that began this journey with them. I am honored at the group's commitment to finish the study with me, and awed by the personal growth and learning I experienced.

\section{Final Study Reflections (Findings)}

Two distinct processes were apparent throughout this study. The first was related to the group's commitment to study FIT principles and test them in teacher-student 
communication when instruction feedback is needed to identify needs for improvement. The second was the action research process and how it moved the group forward toward positive change. This section will reflect on findings from each area.

First, studying and practicing the principles from FIT to Care had a deep impact on participants. Most of the group has been studying Caring Science and were already knowledgeable of Caritas Processes related to relationships with students and each other. Through this study participants learned to apply the theory to their practice as nurse educators. Caring communication techniques grounded in FIT became a tool to maintain a caring trusting relationship between teachers and students when difficult feedback needed to be conveyed. Theory became praxis. The Discovery phases were filled with positive views of how much the group had achieved in their Caritas Journey and a sense of pride and unity from that shared vision. Dreams of the future were well grounded in the 10 Caritas Processes. This provided a shared moral compass and directed them toward a caring culture within and without of the classroom. As we studied face and the use of facework to prevent threats to identity, thoughts turned inward to what was needed to help us maintain our own sense of equanimity. One individual stated, "I have to know what my own face is before I can try to know my students." Participants considered how much pressure we as teachers place on students and how high our expectations are for them. One participant said, "It is almost like we are angry at the students for not meeting our expectations." This was seen as a continuation of "traditional" nursing educational practices. "We learned it from our teachers and now we pass it on down." "Nothing is ever enough. We have to work harder, stay longer, and do more than any other 
discipline." The Caritas Processes teach self-care as the first step in giving care to others. Perhaps these principles can help us to begin to break the cycle of pushing ourselves and our students toward unrealistic expectations.

The group recognized how much they had learned about Caring Science and the positive impact it has had on the teacher-student relationships, but they knew there was room for change. They were able to identify areas that needed change and these were discussed during Design steps. Sometimes the group sensed that students felt "ganged up on" by faculty, and that was a problem that left them feeling uncomfortable. Faculty wanted to "be genuine" and honest with students, not saying one thing to their faces and another behind closed doors in faculty meetings. Mutual understanding was a theme, making sure students know why they are not meeting standards and allowing student input in plans to remediate. Faculty wanted to create caring environments in which a more collegial relationship existed.

In a discussion about teaching in interactive television classrooms, a group member said, “I just can't see them on that little screen; and if I can't see them, I don't know who they are or what it is they need from me." This idea became the overriding theme of Destiny. The theme song from a popular movie, Avatar, is entitled "I See You." To truly 'see' another person takes time and effort; time to pause and consider the other person; who they are and what they need. I must surrender my own view of myself so that I can see through the eyes of the other. Emmanuel Levinas believed that looking into the face of another was looking into the infinity of the universe and into the soul of 
humanity (Levinas, 1969). If teachers could strive to always "see" the face of each student, caring communications would likely become a predictable outcome.

The secondary findings from this study are founded in the action research process. Learning happened and change was realized. Participants learned from one another as we shared what was known and what needed to be learned. The structure provided by the iterative cycles of AR moved the study forward, in spite of the barriers. In the midst of chaos and uncertainty, with little time to commit to the work, as novices to the process, still we moved forward. The process was the intervention. Team building and caring communication flourished. We never lost sight of what was important. As summarized by one participant, "In the long run, at the end of the day, this is about the culture of caring at this university and how this faculty is going to keep that going."

\section{Conclusion and Recommendations}

Action research (AR) is a fluid process that is sculpted into a design unique to a particular setting and to the participants of the individual study. The process itself becomes an instrument of change that is enacted at the intersection of theory and practice. In this study, theory was represented by Feedback Intervention Theory (FIT) and practice was embodied in the caring-trusting relationship between teachers and students. This AR study did not follow a straight line sequence between a starting point and a finish line. It is better envisioned as an impromptu dance moving in irregular repeating spirals across an expanse of time.

Success in an AR study is measured by growth and change brought about from the process. As reported, all participants, including the researcher, recognized both 
personal and professional growth as a result of the study. The spiral of the Caritas Journey continues to move forward for the CON. Findings from this study represent local knowledge and may not be transferable to another setting. However the communication techniques grounded in FIT show promise in strengthening the caring-trusting relationship between teachers and students and in mitigating face threatening messages related to instructional feedback. The FIT to Care Program was not fully utilized in this study. More studies are needed to test the FIT model in undergraduate nursing programs and in other settings in nursing education.

The potential for action research to be used as pedagogy is another area for future study. The growth resulting from this study was impressive, in spite of the participants having very little time to devote to activities above their already crowded schedules. This process could be used in a variety of settings to facilitate group learning and professional development. 


\section{References}

Betcher, D. K. (2010). Elephant in the room project: Improving caring efficacy through effective and compassionate communication with palliative care patients. MEDSURG Nursing, 19(2), 101-105.

Broome, B. S., \& Williams-Evans, S. (2011). Bullying in a caring profession: reasons, results, and recommendations. Journal of Psychosocial Nursing \& Mental Health Services, 49(10), 30-35. doi: http://dx.doi.org/10.3928/02793695-20110831-02

Clarke, P. N., Watson, J., \& Brewer, B. B. (2009). From theory to practice: Caring science according to Watson and Brewer. Nursing Science Quarterly, 22(4), 339345. doi: 10.1177/0894318409344769

Cooperrider, D. L., Whitney, D., \& Stavros, J. M. (2008). Essentials of appreciative inquiry. Brunswick, OH: Crown Custom Publishing.

Creswell, J. W. (2007). Qualitative inquiry \& research design: Choosing among five approaches (2nd ed.). Thousand Oaks, CA: Sage Publications.

Finn, A. N., Schrodt, P., Witt, P. L., Elledge, N., Jernberg, K. A., \& Larson, L. M. (2009). A meta-analytical review of teacher credibility and its associations with teacher behaviors and student outcomes. Communication Education, 58(4), 516537. doi: 10.1080/03634520903131154

Goffman, E. (1982). Interactional ritual: Essays on face-to-face behavior. New York, NY: Pantheon Books.

Goldin, M., \& Kautz, D. D. (2010). Nurturing students during intensive care unit clinical practicum. Dimensions of Critical Care Nursing, 29(5), 238-240 210.1097/DCC.1090b1013e3181e1096cd1055.

Goodboy, A. K., \& Myers, S. A. (2008). The effect of teacher confirmation on student communication and learning outcomes. Communication Education, 57(2), 153179. doi: $10.1080 / 03634520701787777$

Heaslip, V., \& Scammell, J. M. E. (2012). Failing underperforming students: The role of grading in practice assessment. Nurse Education in Practice, 12(2), 95-100. doi: http://dx.doi.org/10.1016/j.nepr.2011.08.003

Heron, J. (1996). Co-operative inquiry: Research into the human condition. London: Sage Publications.

Herr, K., \& Anderson, G. L. (2005). The action research dissertation. Thousand Oaks, CA: Sage Publications. 
Hills, M., \& Mullett, J. (2000). Community-based research: Evidence-based practice for health and social change. Paper presented at the Qualitative Evidence-Based Practice Conference, Coventry University. http://www.leeds.ac.uk/educol/documents/00001388.htm

Hills, M., \& Mullett, J. (2005). Community-based research: a catalyst for transforming primary health care rhetoric into practice. Primary Health Care Research \& Development (Sage Publications, Ltd.), 6(4), 279-290. doi: 10.1191/1463423605pc252oa

Hills, M., \& Watson, J. (2011). Creating a caring curriculum: An emancipatory pedagogy for nursing. New York, NY: Springer Publishing Company.

Kemmis, S., \& McTaggart, R. (2008). Participatory action research: Communicative action and the public sphere. In N. K. Denzin \& Y. S. Lincoln (Eds.), Strategies of qualitative inquiry (3rd ed., pp. 271-330). Thousand Oaks, CA: Sage Publishers, Inc.

Kerssen-Griep, J., Hess, J. A., \& Trees, A. R. (2003). Sustaining the desire to learn: Dimensions of perceived instructional facework related to student involvement and motivation to learn. Western Journal of Communication, 67(4), 357-381.

Kerssen-Griep, J., Trees, A. R., \& Hess, J. A. (2008). Attentive facework during instructional feedback: Key to perceiving mentorship and an optimal learning environment. Communication Education, 57(3), 312-332. doi: $10.1080 / 03634520802027347$

King, P. E., Schrodt, P., \& Weisel, J. J. (2009). The instructional feedback orientation scale: Conceptualizing and validating a new measure for assessing perceptions of instructional feedback. Communication Education, 58(2), 235-261. doi: $10.1080 / 03634520802515705$

Kluger, A. N., \& DeNisi, A. (1996). The effects of feedback interventions on performance: A historical review, a meta-analysis, and a preliminary feedback intervention theory. Psychological Bulletin, 119(2), 254-284. doi: 10.1037/00332909.119.2.254

Lake, P. K. (2012). Communication theory to facilitate teacher caring in instructional feedback. International Journal for Human Caring, 16(4), 27-29.

Levinas, E. (1969). Totality and infinity: An essay for exteriority. Pittsburg, PA: duquesne University Press. 
Malachowski, C. C., \& Martin, M. M. (2011). Instructors' perceptions of teaching behaviors, communication apprehension, and student nonverbal responsiveness in the classroom. Communication Research Reports, 28(2), 141-150. doi: 10.1080/08824096.2011.565275

Smith, C. D., \& King, P. E. (2004). Student feedback sensitivity and the efficacy of feedback interventions in public speaking performance improvement. Communication Education, 53(3), 203-216. doi: 10.1080/0363452042000265152

Sumner, J. (2012). Communication as moral caring in nursing: The moral construct of caring in nursing as communicative action. International Journal for Human Caring, 16(2), 20-27.

Teven, J., \& Monte, M. (2008). Teacher caring in the college classroom: A review of the construct and its correlates. Paper presented at the National Communication Association. http://citation.allacademic.com/meta/p_mla_apa_research_citation/2/5/7/8/9/page s257899/p257899-1.php

Trees, A. R., Kerssen-Griep, J., \& Hess, J. A. (2009). Earning influence by communicating respect: Facework's contributions to effective instructional feedback. Communication Education, 58(3), 397-416. doi: $10.1080 / 03634520802613419$

Watson, J. (2008). Nursing: The philosophy and science of caring (Revised and Updated ed.). Boulder, CO: University Press of Colorado.

Williams, I. R., McDowell, J. B., \& Kautz, D. D. (2011). A caring leadership model for nursing's future. International Journal for Human Caring, 15(1), 31-35. 


\section{Chapter Four}

\section{Summary and Conclusions}

Research studies aimed toward integrating Caring Science into nursing practice and nursing education are becoming more prevalent. The challenge in research is always to translate theory into practice, because theory without practice is no more than words in a book on a shelf. Watson Caring Science Institute and the Caritas Consortium and Caritas Coach program are preparing nurses at all levels to integrate Caritas into their own areas of practice. This study was an attempt to operationalize the concept of caring communication.

Action research methodology was used to bring a group of nursing faculty together to explore using Feedback Intervention Theory (FIT) to strengthen caring communication behaviors during teacher-student interventions to improved student performance without damaging the caring trusting relationship. Outcome validity in AR is manifest by successful resolution of the problem. The participants unanimously agreed that learning and change happened as a result of the study.

For me, learning became personal as well as empirical. Letting the process unfold naturally was my biggest challenge. As I pushed for the study to follow the plans I had so carefully outlined, I became more and more anxious as my plans fell by the wayside. A much more reflexive and impromptu design emerged that met the needs of the group and led us to the desired outcome. In my discomfort over loss of control, I became a good example of how caring communication is not nurtured. I tried to regain balance of power (in my favor) by holding tighter to control and reorganizing my plans rather than 
surrendering to the direction the study took us. I wrote in my journal that if we could use caring in the midst of all the chaos happening in the $\mathrm{CON}$ at the time of our study, we would really accomplish something, and we did. Group process was the key. Journaling did not work as well as group discussions. Team building was facilitated as the group searched for shared meaning and found common ground. The process became the intervention. As we moved through the spiral of AR we began to respond to each other in a more fluid way. Resilience was a theme that could describe the response to outside influences. The group learned to bounce back; to recover quickly and move forward as a team. Caritas Process \#1 includes the self-practice of equanimity, which can be defined as a state of psychological stability. This seemed an important outcome for all participants.

A replication study in a different nursing school setting to see if FIT to Care can be better utilized without the unexpected changes that affected the current study is planned. Using the FIT model in different setting, such as prison nursing, mental health settings, and addiction treatment is also under consideration. These are potentially difficult areas for nurses to maintain caring trusting relationships with patients, especially when the treatment often involves conflict between patient desires and treatment requirements. FIT to Care is a promising program that can be used by nurses to implement caring communication behaviors into teaching and practice. 


\section{References}

Cooperrider, D. L., Whitney, D., \& Stavros, J. M. (2008). Essentials of appreciative inquiry. Brunswick, OH: Crown Custom Publishing.

Heron, J. (1996). Co-operative inquiry: Research into the human condition. London: Sage Publications.

Herr, K., \& Anderson, G. L. (2005). The action research dissertation. Thousand Oaks, CA: Sage Publications.

Hills, M., \& Mullett, J. (2000). Community-based research: Evidence-based practice for health and social change. Paper presented at the Qualitative Evidence-Based Practice Conference, Coventry University. http://www.leeds.ac.uk/educol/documents/00001388.htm

Hills, M., \& Mullett, J. (2005). Community-based research: a catalyst for transforming primary health care rhetoric into practice. Primary Health Care Research \& Development (Sage Publications, Ltd.), 6(4), 279-290. doi: $10.1191 / 1463423605 \mathrm{pc} 252 \mathrm{oa}$

Kerssen-Griep, J., Hess, J. A., \& Trees, A. R. (2003). Sustaining the desire to learn: Dimensions of perceived instructional facework related to student involvement and motivation to learn. Western Journal of Communication, 67(4), 357-381.

Kerssen-Griep, J., Trees, A. R., \& Hess, J. A. (2008). Attentive facework during instructional feedback: Key to perceiving mentorship and an optimal learning environment. Communication Education, 57(3), 312-332. doi: $10.1080 / 03634520802027347$

Kluger, A. N., \& DeNisi, A. (1996). The effects of feedback interventions on performance: A historical review, a meta-analysis, and a preliminary feedback intervention theory. Psychological Bulletin, 119(2), 254-284. doi: 10.1037/00332909.119.2.254

Lake, P. K. (2005). Transformation: Student nurses' experiences in learning the caring process in nursing. International Journal for Human Caring, 9(2), 106-106.

Lake, P. K. (2012). Communication theory to facilitate teacher caring in instructional feedback. International Journal for Human Caring, 16(4), 27-29.

Reason, P. (Ed.). (1988). Human inquiry in action: Developments in a new paradigm research. London: Sage.

Reason, P., \& Bradbury, H. (Eds.). (2001). Handbook of action research: Participative inquiry \& practice. Thousand Oaks, CA: Sage Publlications, Inc. 
Reed, J. (2007). Appreciative inquiry: Research for change. Thousand Oaks,CA: Sage Publications, Inc.

Trees, A. R., Kerssen-Griep, J., \& Hess, J. A. (2009). Earning influence by communicating respect: Facework's contributions to effective instructional feedback. Communication Education, 58(3), 397-416. doi: $10.1080 / 03634520802613419$

Whitney, D., \& Trosten-Bloom, A. (2003). The power of appreciative inquiry: A practical guide to positive change. San Francisco, CA: Berrett-Koehler Publishers, Inc. 


\section{Appendix A \\ Permissions to Use Published Article}

\section{Pamela Lake}

$\begin{array}{ll}\text { From: } & \text { Zane Wolf <wolf@lasalle.edu> } \\ \text { Sent: } & \text { Monday, January 28, 2013 10:24 PM } \\ \text { To: } & \text { Pamela Lake } \\ \text { Cc: } & \text { turkelm@einstein.edu } \\ \text { Subject: } & \text { RE: Permission to use Published article }\end{array}$

Dear Ms Lake:

You have my permission to use the material from your recent article published in the International Journal for Human Caring.

Please cite the article and the permission: International Association for Human Caring grants permission.

Best wishes,

Zane Robinson Wolf, PhD, RN, FAAN

Dean Emerita and Professor

School of Nursing and Health Sciences

La Salle University

Editor, International Journal for Human Caring

St. Benilde Tower 3330

1900 West Olney Avenue

Philadelphia, PA 19141

2159912273

2159912941 (Fax)

wolf@lasalle.edy

From: Pamela Lake [PLake@uttyler.edu]

Sent: Sunday, January 27, 2013 8:46 PM

To: Zane Wolf

Cc: Barbara Haas

Subject: Permission to use Published article

Dr. Wolf,

Please see the attached form requesting permission to use my article that was recently published in the International Journal of Human Caring as part of my dissertation paper.

Thank you for your attention to this,

Pamela K. Lake, PhDc, RN

Clinical Instructor

The University of Texas at Tyler

3900 University Blvd.

Tyler, Texas 75799

plake@uttvleredu

Office: 903-566-7113

Fax: 903-565-5533 


\section{Appendix B \\ Permission to Use Graphic}

Pamela Lake

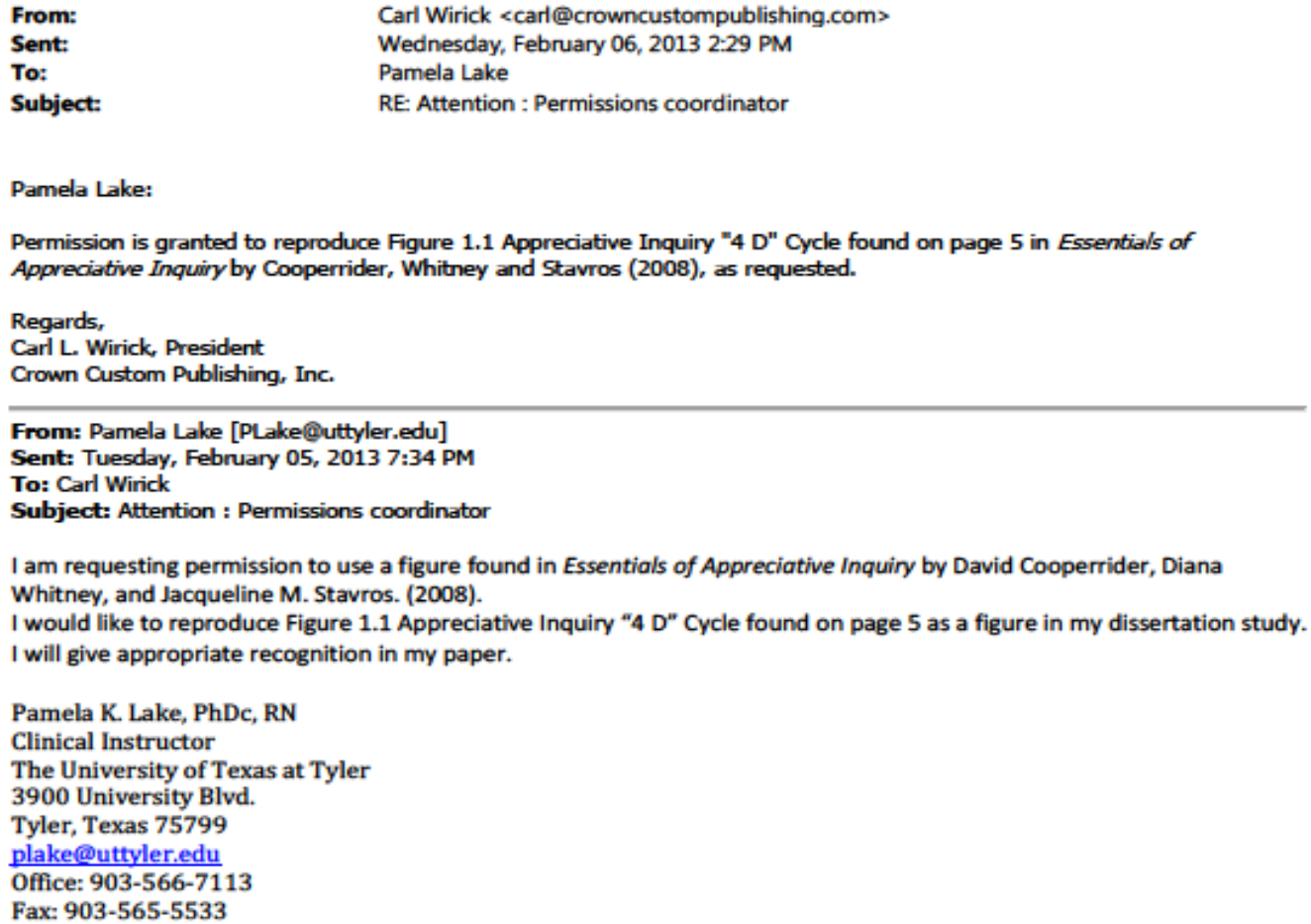

RE: Attention : Permissions coordinator

Pamela Lake:

Permission is granted to reproduce Figure 1.1 Appreciative Inquiry "4 D" Cycle found on page 5 in Essentials of Appreciative Inquiry by Cooperrider, Whitney and Stavros (2008), as requested.

Regards,

Carl L. Wirick, President

Crown Custom Publishing, Inc.

From: Pamela Lake [PLake@uttyler.edu]

Sent: Tuesday, February 05, 2013 7:34 PM

To: Carl Wirick

Subject: Attention : Permissions coordinator

I am requesting permission to use a figure found in Essentials of Appreciative Inquiry by David Cooperrider, Diana Whitney, and Jacqueline M. Stavros. (2008)

I would like to reproduce Figure 1.1 Appreciative Inquiry " $4 \mathrm{D}$ " Cycle found on page 5 as a figure in my dissertation study. I will give appropriate recognition in my paper.

Pamela K. Lake, PhDc, RN

Clinical Instructor

The University of Texas at Tyler

3900 University Blvd.

Tyler, Texas 75799

plake@uttyler.edu

Office: 903-566-7113

Fax: 903-565-5533 


\section{Appendix C \\ Letter of Support from Site}

Dr. Barbara Haas, Associate Dean for Graduate Studies

The University of Texas at Tyler

3900 University Blvd.

Tyler, Texas 75799

July 24,2012

Dear Dr. Haas:

The Division of Nursing at

is pleased to be working with Mrs. Pamela Lake, RN, MSN on her dissertation research. She has been a frequent consultant to us in our process to develop not only caring as our over-riding theoretical framework in our conceptual framework, which I have attached, but has worked with the nursing faculty to implement caring in all aspects of our organizational workings and in providing education to our students. The students know Watson's theory well and are grounded in it from the beginning of their matriculation with us through graduation.

Our conceptual framework was cited positively in our accreditation visit and we continue to strive to utilize and fully implement Watson's theory of human caring as a major curriculum underpinning. Mrs. Lake has worked with us to do all of these things.

That is one of the reasons we are thrilled to have Mrs. Lake consider doing the data collection for her important dissertation research at our organization. We fully expect to have a seamless IRB process later in the summer so that she is approved to conduct this research at our institution. Discussion has already occurred with senior administration regarding this project and they are fully supportive.

The nursing faculty are also supportive and anxious to begin involvement in the research process. As chair, I have allocated time in our schedule of planned meetings for Mrs. Lake to be present and to contact all faculty as part of her project. We look forward to having that happen.

If you require any further information from me, please do not hesitate to contact me at

at

Thank you for your support of this project.

Sincerely,

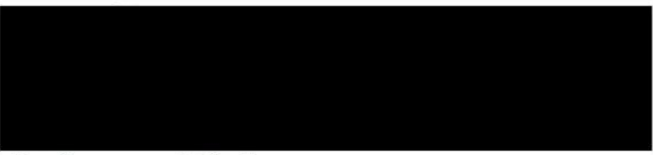

Professor and Chair

Division of Nursing 


\section{Appendix D \\ IRB Approval from UT Tyler}

The University of Texas at Tyler

Institutional Review Board

August 15, 2012

Dear Ms. Lake:

Your request to conduct the study entitled: Caring Communication Behaviors of Nursing Faculty: An Action Research Study is approved as an expedited study, IRB \#Sum2012-111 by The University of Texas at Tyler Institutional Review Board. This approval includes use of the written informed consent for each participant that is attached to this approval letter. In addition, ensure that any research assistants or coinvestigators have completed human protection training, and have forwarded their certificates to the IRB office (G. Duke).

Please review the UT Tyler IRB Principal Investigator Responsibilities, and acknowledge your understanding of these responsibilities and the following through return of this email to the IRB Chair within one week after receipt of this approval letter:

- This approval is for one year, as of the date of the approval letter

- Request for Continuing Review must be completed for projects extending past one year

- Prompt reporting to the UT Tyler IRB of any proposed changes to this research activity

- $\quad$ Any adverse event or unanticipated event MUST be reported promptly to academic administration (chair/dean), and to the IRB.

- Suspension or termination of approval may be done if there is evidence of any serious or continuing noncompliance with Federal Regulations or any aberrations in original proposal.

- Any change in proposal procedures must be promptly reported to the IRB prior to implementing any changes except when necessary to eliminate apparent immediate hazards to the subject.

Best of luck in your research, and do not hesitate to contact me if you need any further assistance.

Sincerely,

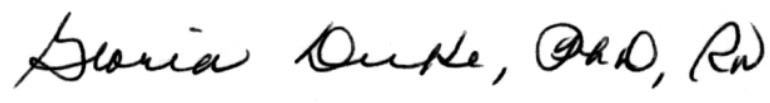

Gloria Duke, $\mathrm{PhD}, \mathrm{RN}$

Chair, UT Tyler IRB 
Appendix E

IRB Approval from Site University

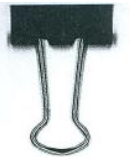

REVIEW OF HUMAN PARTICIPANTS RESEARCH

This application must be completed in Microsoft Word when submitted. Handwritten applications will not be accepted.

Title of project: Caring Communication Behaviors of Nursing Faculty: An Action Research Study

I agree to provide the proper surveillance of this project to ensure that the rights and welfare of the human participants are properly protected. Additions to or changes in procedures affecting the participants after the project has been approved will be submitted to the committee for review.

PRINCIPAL INVESTIGATOR(S):

(if student, list advisor's name last)

Pamela K. Lake

Typed Name

Barbara Haas

Typed Name

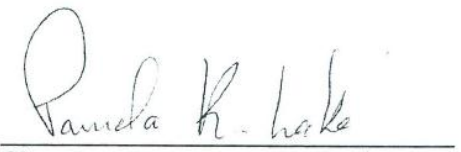

Signature

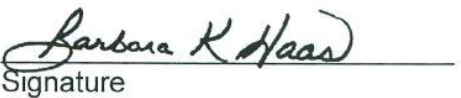

Typed Name

Signature

CON

Department

The University of Texas at Tyler

3900 University Blvd.

Tyler, Texas 75799

Faculty Member's Campus Address

College

123 Woodlawn Ave

Jacksonville Texas 75766

Student's Address

903-566-7021

Campus Phone Number

903-721-1101

Phone Number 


\section{Appendix E continued}

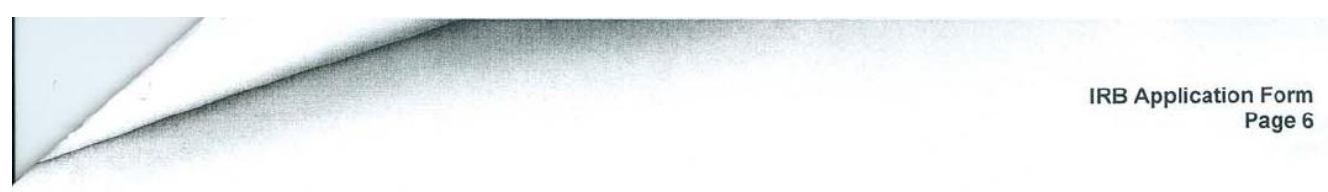

Checklist for Review

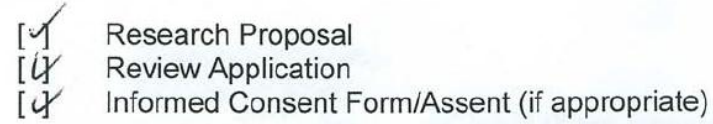

\begin{tabular}{|c|c|c|c|}
\hline Name of Reviewer: & Approved & Not Approved & Comments: \\
\hline Curti' Cork & & & \\
\hline Micke Zyuedler & $x$ & & \\
\hline B. Nam-ford & $\sim$ & & \\
\hline & & & \\
\hline & & & \\
\hline & & & \\
\hline & & & \\
\hline & & & \\
\hline & & & \\
\hline & & & \\
\hline
\end{tabular}




\section{Appendix F \\ Demographic Survey \\ Faculty Demographic Survey}

1. What is the title of your position?

_ Clinical Faculty/ Lecturer

_ Assistant Professor

Associate Professor

_ Professor

Other

2. Are you a full-time or part-time faculty member?

_ Full-time

_ Part-time

3. What is the highest level of education you have earned?
_ Bachelor's degree
_ Master's degree
_ Doctoral degree
Other:

4. How long have you been teaching, including all faculty positions you have held?

Less than 1 year

- 1-5 years

- 6-10 years

- 11-15 years

- 16-20 years

_ Over 20 years

5. How long have you been teaching at this institution?

Less than 1 year

$-1-5$ years

- 6-10 years

_ Over 10 years

6. What is your age? 
7. What is your gender?

_ Male

_ Female

8. What is your race?

_ African-American

Asian

_ White/Caucasian

_Other

9. Are you Hispanic?

$$
\begin{aligned}
& \text { Yes } \\
& \text { — No }
\end{aligned}
$$


BIOGRAPHICAL SKETCH

\begin{tabular}{|c|c|c|c|}
\hline \multirow{2}{*}{$\begin{array}{l}\text { NAME } \\
\text { Pamela K Lake } \\
\text { COMMONS USER NAME (credential, } \\
\text { e.g., agency login) } \\
\text { Pamela K. Lake, PhDc,RN }\end{array}$} & \multirow{2}{*}{\multicolumn{2}{|c|}{$\begin{array}{l}\text { POSITION TITLE } \\
\text { Instructor }\end{array}$}} & \\
\hline & & & \\
\hline \multicolumn{4}{|l|}{ EDUCATION/TRAINING } \\
\hline INSTITUTION AND LOCATION & $\begin{array}{l}\text { DEGREE } \\
\text { (if applicable) }\end{array}$ & YEAR & FIELD OF STUDY \\
\hline Texas Woman's University & BSN & 05/1975 & Nursing \\
\hline University of Texas at Tyler & MSN & $12 / 2004$ & Nursing/Education \\
\hline University of Texas at Tyler & $\mathrm{PhD}$ & 05/2013 & Nursing \\
\hline $\begin{array}{l}\text { International Certification } \\
\text { Program in Human Caring and } \\
\text { Healing }\end{array}$ & $\mathrm{N} / \mathrm{A}$ & 05/2007 & $\mathrm{N} / \mathrm{A}$ \\
\hline $\begin{array}{l}\text { Caritas Coach Education } \\
\text { Program Certification }\end{array}$ & $\mathrm{N} / \mathrm{A}$ & $4 / 2009$ & N/A \\
\hline
\end{tabular}

\section{POSITIONS}

$\begin{array}{llll}\text { 2008-present } & \text { Clinical Instructor } & \text { University of Texas at Tyler } & \text { Tyler, Texas } \\ \text { 2007-2008 } & \text { Adjunct Clinical Instructor } & \text { University of Colorado HSC } & \text { Denver, Colorado } \\ 2004-2007 & \text { Senior Lecturer } & \text { University of Texas at Tyler } & \text { Tyler, Texas } \\ \text { 2006 (Summer) } & \text { Surveyor for DADS } & \text { NACES Plus } & \text { Austin, Texas } \\ \text { 2003- 2005 } & \text { PRN RN staff (Med/Surg, Psych) } & \text { East Texas Medical Center } & \text { Tyler, Texas } \\ \text { 2002- 2003 } & \text { Staffing Agency } & \text { Extranurse.com } & \text { Tyler, Texas } \\ \text { 2000- 2001 } & \text { Weekend RN Supervisor } & \text { Twin Oaks Convalescent Care } & \text { Jacksonville, TX } \\ \text { 2000- 2001 } & \text { RN PRN Pool/ Med-Surg } & \text { Trinity Mother Frances Hospital } & \text { Tyler, Texas } \\ \text { 1999- 2004 } & \text { Clinical Instructor, ADN Program } & \text { Tyler Junior College } & \text { Tyler, Texas } \\ \text { 1996- 1999 } & \text { Branch Manager; Nurse Educator } & \text { Mother Frances Home Health } & \text { Tyler, Texas }\end{array}$


1994- 1995

1993- 1994

1990- 1993

1990- 1990

1988- 1990

1985- 1988

1983- 1985

1980- 1983

1977- 1980

1975- 1977
Service Director

Unit Director of Nurses

Correctional Charge

PRN Pool

Office Nurse

Nan Travis Hospital

Dr. Wm. Milawski

Director Home Health Nan Travis Hospital

Medicare Supervisor Texas Star Home Health

Visiting Nurse

Cherokee Home Health

Psychiatric Charge Nurse

Rusk State Hospital

Supervisor ICU

Newburn Memorial Hospital
Jacksonville, TX

Tennessee Colony, Texas

Rusk, Texas

Jacksonville, Texas

Jacksonville, Texas

Jacksonville, Texas

Jacksonville, Texas

Jacksonville, Texas

Rusk, Texas

Jacksonville, Texas

\section{Academic and Professional Honors}

STTI

ANA

TNA

IAHC

HNA

STTI Rising Star in Research, 2005

\section{Publications}

1. Lake, P. K. (2005). Transformation: Student nurses' experiences in learning the caring process in nursing. International Journal for Human Caring, 9(2), 106-106.

2. Lake, P. K. (2012). Communication theory to facilitate teacher caring in instructional feedback. International Journal for Human Caring, 16(4), 2729. 